Marcin Lysko

Uniwersytet w Białymstoku e-mail: marcin.lysko@uwb.edu.pl

\title{
Zasady obsady personalnej kolegiów karno-administracyjnych Polski Ludowej*
}

\begin{abstract}
SUMMARY
Officers of the Boards Judging Petty Offences in the People's Republic of Poland

In December 1951 the collective model of judging petty offences in Poland was introduced. The boards judging petty offences, with non-professionals as their members, were situated as branch of local administration. The candidates to these boards were proposed by the state's enterprises and by the local societies, the members were elected by the local administration - so called "rady narodowe" (people's councils). After the political crisis of 1956 this model was strongly criticized and non-professional members were singled as the most important reason of low level of judgments. In 1958 additional new requirement was introduced: the chairmen of the boards and their deputies had to get the university degree in legal science. The election of new members in the 60's changed the situation and the professionals partially replaced the "social lay participants" in this kind of administration of justice. The leading positions in the boards were transferred to members of the security apparatus. As a result, the bureaucratic factor was playing the dominant role in the boards judging petty offences in the communist Poland.
\end{abstract}

Key words: boards judging petty offences, people's councils, social lay participants.

I.

Ustawa z 15 grudnia 1951 r. o orzecznictwie karno-administracyjnym ${ }^{1}$ (u.ok.a.) powierzyła rozstrzyganie spraw o wykroczenia organom kolegialnym funkcjonującym w oparciu o czynnik społeczny. Powołane do życia celem orzekania w sprawach o wykroczenia kolegia początkowo nie posiadały specjalnej

\footnotetext{
* Projekt został sfinansowany ze środków Narodowego Centrum Nauki jako projekt badawczy własny nr NN 110189540.

1 Dz. U. Nr 66, poz. 454.
} 
nazwy, chociaż w potocznym języku określano je mianem kolegiów orzekających. Po objęciu steru rządów w Polsce przez Władysława Gomułkę zaczęto posługiwać się terminem ,kolegia karno-administracyjne”2, który zyskał rangę ustawową poprzez zamieszczenie w znowelizowanej 2 grudnia 1958 r. u.ok.a. ${ }^{3}$ Wraz z wejściem w życie 1 stycznia 1972 r. kompleksowej kodyfikacji prawa wykroczeń Polski Ludowej zostaną utworzone kolegia do spraw wykroczeń4, co uzasadnia przyjęcie jako ram czasowych niniejszego artykułu z lat 1957-1971, czyli okresu, w którym funkcjonowały kolegia karno-administracyjne.

Kolegia utworzono przy terenowych organach administracji państwowej prezydiach rad narodowych, począwszy od najniższego szczebla podziału terytorialnego, jakim były gromady (zastąpiły w 1954 r. gminy), a skończywszy na prezydiach wojewódzkich rad narodowych. Podstawowym ogniwem systemu orzecznictwa karno-administracyjnego były kolegia przy prezydiach powiatowych rad narodowych, które jako organy I instancji dysponowały pełną gamą uprawnień przewidzianych u.ok.a. Były one również instancją odwoławczą od orzeczeń kolegiów działających przy prezydiach rad narodowych szczebla niższego niż powiat, czyli kolegiów gromadzkich, osiedlowych i miast liczących poniżej 10 tys. mieszkańców ${ }^{5}$. Usytuowanie kolegiów w strukturach terenowej administracji ogólnej skutkowało powierzeniem prezydiom rad narodowych „bezpośredniego nadzoru” nad działalnością podległych im kolegiów w drodze wydawania „wytycznych dla orzecznictwa i kontroli ich wykonania"6. "Zwierzchni nadzór" nad orzecznictwem kolegiów sprawował minister spraw wewnętrznych za pośrednictwem Biura Nadzoru nad Orzecznictwem Karno-Administracyjnym (Biuro Nadzoru), które w 1958 r. zostanie przekształcone w Departament Społeczno-Administracyjny (DSA) 7 .

2 Terminem „kolegia karno-administracyjne” posłużyli się m.in. w pierwszej połowie $1957 \mathrm{r}$. Z. Rybicki i K. Sobczak w artykule O niektórych zagadnieniach udziału obywateli w orzecznictwie karno-administracyjnym, „Nowe Prawo” 1957, nr 4.

3 Ustawa z dnia 2 grudnia 1958 r. o zmianie ustawy z dnia 15 grudnia 1951 r. o orzecznictwie karno-administracyjnym (Dz. U. Nr 77, poz. 396).

4 O ustroju kolegiów do spraw wykroczeń, "Zagadnienia Karno-Administracyjne” (dalej: ZKA) 1971, nr 3, s. 19.

5 K. Siarkiewicz, Kształtowanie się ustroju kolegiów, „Zagadnienia Wykroczeń” (dalej: ZW) 1977, nr 4-5, s. 37.

6 Prezydia wojewódzkich rad narodowych posiadły ponadto możliwość uchylania w trybie nadzoru prawomocnych orzeczeń, w przypadku stwierdzenia ich nielegalności lub „oczywistej niesłuszności”. M. Jaroszyński, Zagadnienia rad narodowych, Warszawa 1961, s. 229.

7 Przed reaktywowaniem pod koniec 1954 r. Ministerstwa Spraw Wewnętrznych zwierzchni nadzór nad orzecznictwem karno-administracyjnym sprawowało Biuro Społeczno-Administracyjne Urzędu Rady Ministrów. Z kolei w 1958 r. Biuro Nadzoru zostanie przekształcone w Departament Społeczno-Administracyjny, którego zakres kompetencji ulegnie znacznemu rozszerzeniu o kwestie niezwiązane bezpośrednio z orzecznictwem karno-administracyjnym. W ramach Departamentu Społeczno-Administracyjnego MSW nadzór nad działalnością kolegiów wykonywał Wydział Karno-Administracyjny. I. Przybysiak, Od „Biuletynu” do „Zagadnień Wykroczeń", ZW 1976, nr 2, s. 22-23. 
W skład kolegium wchodzili wybierani przez rady narodowe przewodniczący, jego zastępca i członkowie. Zarówno u.ok.a., jak i wydane na jej podstawie rozporządzenie Rady Ministrów ${ }^{8}$ nie wymagały od członków kolegiów żadnych kwalifikacji zawodowych. Wprowadzały natomiast pewne formalne kryteria, ograniczające krąg osób pełniących najbardziej odpowiedzialne funkcje w kolegiach do osób związanych z radami narodowymi oraz ich organami wykonawczo-zarządzającymi, jakimi były prezydia. Wobec trudnej sytuacji kadrowej administracji terenowej $\mathrm{w}$ pierwszej połowie lat pięćdziesiątych ograniczenia te w poważnym stopniu utrudniały wprowadzenie do kolegiów osób posiadających kwalifikacje prawnicze ${ }^{9}$. Przewodniczącego kolegium i zastępcę wybierano bowiem spośród członków i pracowników prezydium rady narodowej, przy którym funkcjonowało kolegium. Ponadto przewodniczący kolegium i jego zastępca zostali obarczeni obowiązkiem kierowania pracami składów orzekających kolegiów, które rozpatrywały sprawy o wykroczenia w trzyosobowych kompletach ${ }^{10}$. Jeżeli przewodniczący kolegium lub jego zastępca nie byli w stanie osobiście przewodniczyć rozprawie, wówczas mogli wyznaczyć przewodniczącym składu orzekającego członka kolegium, który piastował mandat radnego ${ }^{11}$. Natomiast pozostali członkowie kolegiów reprezentujący tzw. aktyw społeczny rekrutowali się spośród radnych oraz przedstawicieli zakładów pracy i organizacji społecznych.

Oparcie składu kolegiów na czynniku społecznym określano mianem demokratyzacji procesu rozstrzygania spraw o wykroczenia ${ }^{12}$. Powierzenie przedstawicielom społeczeństwa zadań stanowiących tradycyjnie domenę funkcji urzędniczych miało podnieść rangę orzecznictwa karno-administracyjnego poprzez wzmocnienie jego funkcji wychowawczej, która odgrywała szczególnie ważną rolę ,jjako moment decydujący o skuteczności walki z czynami zakłócającymi ład społeczny"13. Twierdzono przy tym, że udział w rozstrzyganiu spraw o wykroczenia osób posiadających doświadczenie życiowe oraz znajo-

8 Rozporządzenie Rady Ministrów z dnia 15 grudnia 1951 r. w sprawie trybu wybierania i odwoływania członków kolegiów przy prezydiach rad narodowych (Dz. U. Nr 66, poz. 455).

9 J. Skupiński, Skład społeczny kolegiów karno-administracyjnych, „Problemy Rad Narodowych” 1969, nr 14, s. 82.

10 Oparta na zasadzie kontradyktoryjności rozprawa przed kolegium była przewidziana przez u.ok.a. jako podstawowy tryb rozpatrywania spraw o wykroczenia. $\mathrm{Z}$ kolei $\mathrm{w}$ ramach posiadającego inkwizycyjny charakter postępowania nakazowego przewodniczący kolegium mógł orzec karę grzywny lub pracy poprawczej w ograniczonym wymiarze. Przesłanką rozpatrzenia sprawy w trybie postępowania nakazowego była mała szkodliwość społeczna czynu zarzucanego obwinionemu, stąd dotyczyło ono w praktyce spraw „prostszych, wynikających z zawiadomień władz, urzędów państwowych, instytucji i zakładów pracy". Z. Rybicki, Gospodarcze aspekty orzecznictwa karno-administracyjnego, „Przegląd Ustawodawstwa Gospodarczego" 1952, nr 9, s. 322.

11 J. Skupiński, Model polskiego prawa o wykroczeniach, Warszawa 1974, s. 115.

12 M. Broniatowski, Perspektywy uspołecznienia orzecznictwa karno-administracyjnego, „Państwo i Prawo” (dalej: PiP) 1962, nr 7, s. 73.

13 Głos maja przedstawiciele nauki, ZKA 1961, nr 6, s. 35. 
mość problemów danego terenu i zamieszkujących go ludzi umożliwiał władzy orzekającej „bardziej wszechstronne zbadanie okoliczności sprawy”. Z kolei powoływanie do kolegiów osób zatrudnionych w zakładach pracy położonych na obszarze danej jednostki terytorialnej miało przyczynić się „do lepszego zrozumienia podłoża popełnianych wykroczeń” oraz ich wnikliwej oceny przez kolegium ${ }^{14}$.

Wobec oparcia składu osobowego kolegiów na czynniku społecznym regulacje procesowe u.ok.a. były dosyć ogólnikowe, co wynikało z dążenia ustawodawcy do „przesadnej prostoty i lakoniczności”15. Krótkie i zwięzłe przepisy ustawy miały być łatwe do zrozumienia przez nieposiadających wykształcenia prawniczego członków składów orzekających kolegiów ${ }^{16}$. Pomimo sprowadzenia do minimum formalistyki postępowania karno-administracyjnego na fali wydarzeń 1956 r. oficjalnie przyznano, iż „zaznajomienie się z przepisami prawa dotyczącymi wykroczeń z najróżnorodniejszych dziedzin oraz opanowanie w całej pełni trybu postępowania" sprawiało duże problemy zasiadającym w kolegiach przedstawicielom czynnika społecznego. Podkreślił to w wywiadzie opublikowanym na łamach „Prawa i Życia” nowy minister spraw wewnętrznych Władysław Wicha, który w braku odpowiedniego przygotowania fachowego członków składów orzekających upatrywał podstawową przyczynę słabego poziomu funkcjonowania kolegiów ${ }^{17}$. Nieposiadające kwalifikacji fachowych oraz niedoświadczone składy orzekające kolegiów okresu stalinowskiego stykały się ze skomplikowaną materią prawa karno-administracyjnego, którego „przepisy były nie tylko liczne i bardzo rozproszone, lecz także zawarte $\mathrm{w}$ aktach prawnych pochodzących $\mathrm{z}$ różnych okresów i należących do różnych gałęzi prawa"18.

Krytyczna ocena idei powierzenia orzecznictwa karno-administracyjnego wyłącznie czynnikowi społecznemu została także wyrażona w raporcie Ministerstwa Kontroli Państwowej (MKP) sporządzonym na podstawie analizy wyników przeprowadzonej w drugiej połowie 1956 r. kontroli działalności kolegiów w wybranych województwach. Skierowany na ręce dyrektora Biura Nadzoru Henryka Chmielewskiego ${ }^{19}$ raport wskazywał na pilną potrzebę wpro-

14 Z. Rybicki, K. Sobczak, op. cit., s. 37.

15 Notatka Informacyjna dla Kolegium Ministerstwa o przebiegu orzecznictwa karno-administracyjnego w 1955 r., Instytut Pamięci Narodowej w Warszawie, Biuro Udostępniania i Archiwizacji Dokumentów, zespół akt Ministerstwo Spraw Wewnętrznych II, sygn. teczki 6443, s. 33 (IPN BUiAD MSW II 6443, s. 33).

16 Uzasadnienie projektu noweli do ustawy z dnia 15 grudnia 1951 r. o orzecznictwie karno-administracyjnym, IPN BUiAD MSW II 6439, s. 404.

17 "Zadaniem MSW jest walka ze wszelkimi jawnymi lub ukrytymi formami dyskryminacji narodowej..." wywiad z Ministrem Spraw Wewnętrznych Władysławem Wichą, „Prawo i Życie” (dalej: PiŻ) 1956, nr 5, s. 3.

18 J. Skupiński, Skład społeczny kolegiów..., s. 82.

19 Henryk Chmielewski (1907-1970) w pierwszych latach Polski Ludowej był wysokiej rangi funk- 
wadzenia szeregu zmian w u.ok.a., gdyż „dotychczasowe przepisy zawarte w ustawie z 1951 r. w znacznym stopniu są obecnie nieaktualne, a nawet $\mathrm{w}$ niektórych wypadkach stanowią jedną z przyczyn hamujących pracę kolegiów"20. Uwaga ta dotyczyła zwłaszcza braku fachowego przewodnictwa kolegiów, gdyż zarówno w przypadku przewodniczącego kolegium, jak i jego zastępcy u.ok.a. nie przewidywała wymogu posiadania wykształcenia prawniczego, chociaż osoby te odgrywały kluczową rolę w postępowaniu karno-administracyjnym. Na podstawie analizy wniosku o ukaranie przewodniczący kolegium podejmował decyzję co do wszczęcia postępowania i dalszego biegu sprawy, która mogła być rozpatrzona na rozprawie, załatwiona w trybie nakazowym bez przeprowadzenia rozprawy lub przekazana na drogę postępowania sądowego ${ }^{21}$.

Wprawdzie przewodniczący kolegiów z racji zasiadania w prezydium rady narodowej posiadali ogólną wiedzę w zakresie funkcjonowania rad narodowych, lecz rzadko kiedy byli prawnikami, a tym bardziej fachowcami w dziedzinie prawa karno-administracyjnego ${ }^{22}$. Zasiadanie $\mathrm{w}$ prezydium nie wiązało się z wymogiem posiadania określonego poziomu wykształcenia ani kwali-

cjonariuszem Ministerstwa Bezpieczeństwa Publicznego. Od lipca 1946 r. do października 1949 r. pełnił funkcję wicedyrektora Departamentu V Ministerstwa Bezpieczeństwa Publicznego zajmującego się inwigilacją Kościoła rzymskokatolickiego oraz kontrolą stowarzyszeń i organizacji społecznych. Pod koniec października 1949 r. został przeniesiony do pracy w Departamencie Nadzoru Sądowego Ministerstwa Sprawiedliwości. Pełniąc funkcję dyrektora tego departamentu, przyczynił się do zorganizowania tzw. Sekcji Tajnej Sądu Najwyższego. Utworzona z inicjatywy kierownictwa Ministerstwa Bezpieczeństwa Publicznego Sekcja Tajna SN pełniła rolę sądu II instancji wobec powołanej w połowie 1950 r. sekcji tajnej Sądu Apelacyjnego (od 1951 r. Wojewódzkiego) w Warszawie. Sądy tajne rozpatrywały sprawy osób zakwalifikowanych przez bezpiekę do grupy wrogów Polski Ludowej, którym wytaczano procesy o szpiegostwo, współpracę z hitlerowcami lub o tzw. faszyzację życia w II Rzeczypospolitej. Prowadzone pod dyktando bezpieki procesy polityczne przed sądami tajnymi kończyły się wyrokami długoletniego więzienia, a w wielu przypadkach orzeczeniem kary śmierci. Na fali polityki odwilży sądy tajne zaprzestały działalności w pierwszej połowie 1955 r., osoby zaś z nimi związane, w tym Henryk Chmielewski, nie zostały nigdy pociągnięte do odpowiedzialności za swoją zbrodniczą działalność. W $1955 \mathrm{r}$. Henryk Chmielewski objął stanowisko dyrektora Biura Nadzoru, a następnie kierował powstałym w $1958 \mathrm{r}$. z przekształcenia Biura Nadzoru Departamentem Społeczno-Administracyjnym. Kiedy w 1964 r. nowy minister spraw wewnętrznych Mieczysław Moczar powołał w jego miejsce Zygmunta Orłowskiego, Chmielewski odszedł z pracy w MSW i zajął się działalnością pisarską. Był m.in. autorem powieści Prorok wydanej już po jego śmierci w $1971 \mathrm{r}$.

20 Uwagi i spostrzeżenia w sprawie orzecznictwa karno-administracyjnego. Raport Ministerstwa Kontroli Państwowej z dnia 11 stycznia 1957 r. IPN BU MSW II 6443, s. 50. M. Zimmermann, Orzecznictwo karno-administracyjne, ZKA 1965, nr 4, s. 12-13.

22 Przykładowo podczas przypadającej na lata 1958-1961 kadencji rad narodowych w skład ich prezydiów wchodziło 37800 członków, z czego 11 tys. stanowili stali członkowie. Wyższe wykształcenie posiadało zaledwie 1030 spośród nich, lecz tylko 183 członków prezydiów było prawnikami. Wykształceniem średnim legitymowało się 18\% członków prezydiów, czyli 6800 osób. Wykształcenie podstawowe pełne (ukończonych 7 klas) posiadało 43\% członków prezydiów (16 400), zaś wykształcenie podstawowe niepełne 36\%, czyli 13550 członków prezydiów. J. Hibner, Ludzie władzy terenowej, PiŻ 1961, nr 8, s. 5. 
fikacji zawodowych ${ }^{23}$, chociaż w praktyce dokonując wyboru członków prezydiów, rady narodowe kierowały się założeniem „doboru [...] osób o najlepszych kwalifikacjach politycznych, moralnych i zawodowych"24. Przewodniczący prezydium, jego zastępcy oraz sekretarz byli stale urzędującymi pracownikami prezydium otrzymującymi z tego tytułu wynagrodzenie, natomiast pozostali członkowie prezydium pełnili swoje funkcje społecznie ${ }^{25}$. Ponieważ przewodniczący kolegium pełnił jednocześnie odpowiedzialną funkcję członka prezydium rady narodowej, stąd nie był w stanie poświęcić należytej uwagi orzecznictwu karno-administracyjnemu. W praktyce bieżącą pracą kolegiów kierowali zastępcy przewodniczącego, wywodzący się spośród pracowników prezydium lub radnych rady narodowej. Fakt wykonywania przez zastępców przewodniczącego wszelkich zadań związanych z kierowaniem pracą kolegium uniemożliwiał im osobiste przewodniczenie w składach orzekających ${ }^{26}$.

Raport MKP zwracał szczególną uwagę na brak fachowego kierownictwa poszczególnych składów orzekających kolegiów, krytycznie oceniając przewidzianą w u.ok.a. możliwość wyznaczenia przewodniczącym składu orzekającego członka kolegium będącego jednocześnie radnym. Rozwiązanie to wyłączało ze składów orzekających kolegiów osoby przewodniczącego kolegium i jego zastępcy, którzy $\mathrm{z}$ racji doświadczenia nabytego $\mathrm{w}$ związku z pracą w prezydium rady narodowej „mogliby wywierać poważny wpływ na prawidłowość pracy całego składu orzekającego”. Wobec powszechnej praktyki wyznaczania radnych na przewodniczących składów orzekających pozbawione fachowego kierownictwa „kolegia wprowadzały dowolność w wymierzaniu kar lub wydawały orzeczenia bez jakiejkolwiek podstawy prawnej"27.

Jako organy wykonawczo-zarządzające rad narodowych prezydia miały „pozostać pod względem swojego składu organem jednorodnym z radą, tj. organem ludowym, niezawodowym". M. Jaroszyński, Zagadnienia rad narodowych, Warszawa 1961, s. 193. A. Wendel, Z. Zell, Rady narodowe w PRL, Warszawa 1968, s. 137.

Według postanowień ustawy z 2 stycznia 1958 r. o radach narodowych (Dz. U. Nr 5, poz. 58) w skład prezydium wojewódzkiej rady narodowej oprócz przewodniczącego, 3 zastępców i sekretarza wchodziło nie więcej niż 4 członków prezydium pełniących swoje obowiązki społecznie. Na szczeblu powiatowym prezydium składało się z przewodniczącego, zastępcy, sekretarza oraz członków w liczbie nieprzekraczającej 3. Z. Leoński, Rady narodowe. Zasady funkcjonowania $i$ organizacja, Warszawa 1969, s. 136-137.

Z. Rybicki, K. Sobczak, op. cit., s. 37.

27 Wskazuje na to przytoczony w raporcie MKP przykład województwa wrocławskiego, gdzie w 1956 r. „kolegium odwoławcze przy prezydium WRN we Wrocławiu na 88 orzeczeń wydanych w sprawach pozaskupowych uchyliło 21 orzeczeń z powodu nieprzestrzegania właściwych przepisów prawnych przez kolegia szczebla powiatowego, a w 42 przypadkach stwierdzono w orzeczeniach brak podstawy prawnej do ukarania obwinionych". Natomiast dowolność w wymierzaniu kar polegała na orzekaniu grzywien w wysokości niewspółmiernej do wagi czynu popełnionego przez osobę obwinioną, np. „za palenie papierosów w sklepie lub pozostawienie bez opieki konia na ulicy wymierzano grzywny tej samej wysokości jak za wybryki pijańskie i chuligańskie". Uwagi i spostrzeżenia w sprawie orzecznictwa karno-administracyjnego. Raport Ministerstwa Kontroli Państwowej z dnia 11 stycznia 1957 r. IPN BU MSW II 6443, s. 52. 
Raport MKP przyczyn braku przygotowania fachowego członków kolegiów upatrywał $\mathrm{w}$ trybie powoływania kolegiów orzekających, który nie gwarantował wyboru osób posiadających odpowiednie kwalifikacje do wykonywania orzecznictwa karno-administracyjnego. Zgodnie z rozporządzeniem wykonawczym do u.ok.a. ${ }^{28}$ listy kandydatów na członków kolegiów sporządzało prezydium rady narodowej $\mathrm{w}$ oparciu o zgłoszenia dokonane przez zakłady pracy i organizacje społeczne. W praktyce zakłady pracy i organizacje społeczne podchodziły do nałożonego na nie obowiązku w sposób formalistyczny, wskutek czego typowanie kandydatów na członków kolegiów odbywało się bez uprzedniego sprawdzenia kwalifikacji kandydatów oraz ich podejścia do wykonywania odpowiedzialnej funkcji członka kolegium. Osoby wskazane przez zakłady pracy i organizacje społeczne były umieszczane na listach kandydatów sporządzanych przez prezydia rad narodowych, które także nie zadawały sobie trudu sprawdzenia przydatności kandydatów do pracy w kolegium. Także dokonujące wyboru członków kolegiów rady narodowe ograniczały się do mechanicznego zatwierdzania list kandydatów bez przeprowadzenia analizy sylwetek poszczególnych kandydatów. Powołani w taki sposób członkowie kolegiów nie poczuwali się do odpowiedzialności za wyniki swojej pracy zarówno przed radą narodową, która ich wybrała, jak też typującą ich organizacją społeczną czy załogą zakładu pracy. Traktowanie procesu powoływania kolegiów w kategoriach zła koniecznego nie pozostawało bez wpływu na postawę ich członków, gdyż „większość wybranych członków kolegiów nie wykazywała aktywności", a przeszło połowa w ogóle nie brała udziału w posiedzeniach ${ }^{29}$.

Zawarte $\mathrm{w}$ raporcie MKP uwagi krytyczne znalazły swoje potwierdzenie $\mathrm{w}$ przebiegu pierwszych w okresie gomułkowskim wyborów do kolegiów, które odbyły się w I kwartale 1957 r. Celem odejścia od praktyki mechanicznego sporządzania przez prezydia list kandydatów i automatycznego zatwierdzania tych list przez rady narodowe Biuro Nadzoru przekazało prezydiom rad narodowych odpowiednie materiały instrukcyjne i wysłało w teren inspektorów, którzy „brali udział w posiedzeniach prezydiów i sesjach plenarnych rad narodowych". Podejmowane przez Biuro Nadzoru działania nie przyczyniły się do zwiększenia zainteresowania rad narodowych i ich prezydiów wyborami. Wybory przeprowadzono w sposób formalny, powołując na członków kolegiów szereg osób mało przydatnych. Stwierdzono przy tym „wypadki lekceważenia terminów wyborczych" przez rady narodowe, wskutek czego niektóre kolegia wybrano z kilkudniowym opóźnieniem ${ }^{30}$.

28 Rozporządzenie Rady Ministrów z dnia 16 grudnia 1951 r. w sprawie trybu wybierania i odwoływania członków kolegiów przy prezydiach rad narodowych (Dz. U. Nr 66, poz. 455).

29 Uwagi i spostrzeżenia w sprawie orzecznictwa karno-administracyjnego. Raport Ministerstwa Kontroli Państwowej z dnia 11 stycznia 1957 r. IPN BU MSW II 6443, s. 51-52.

30 Sprawozdanie z działalności orzecznictwa karno-administracyjnego w 1957 r., IPN BU MSW II 16155 , s. 4. 
II.

Wobec powszechnej krytyki rozwiązań u.ok.a. Biuro Nadzoru podjęło w pierwszej połowie $1957 \mathrm{r}$. prace nad nowelizacją ustawy, podczas których w centrum uwagi postawiono problem wprowadzenia do kolegiów czynnika fachowego. Przyjęta przez Sejm 2 grudnia 1958 r. nowelizacja u.ok.a. zakładała obsadzenie funkcji przewodniczącego oraz zastępcy przewodniczącego kolegium wojewódzkiego i powiatowego osobami posiadającymi ukończone studia prawnicze. Udziału czynnika fachowego nie przewidziano w kolegiach szczebla niższego niż powiat ${ }^{31}$, gdyż celem zmniejszenia nadmiernie rozbudowanej struktury organizacyjnej orzecznictwa karno-administracyjnego zrezygnowano z obligatoryjnego powoływania kolegiów gromadzkich, osiedlowych miast niestanowiących powiatów ${ }^{32}$. Kolegia takie mogły być tworzone na mocy uchwał odpowiednich rad narodowych, które to uchwały wymagały zatwierdzenia przez powiatową radę narodową ${ }^{33}$.

Celem lepszego nasycenia kolegiów powiatowych i wojewódzkich czynnikiem fachowym zniesiono ograniczenia kręgu osób, spośród których rada narodowa mogła dokonać wyboru przewodniczącego kolegium i jego zastępcy. Kandydaci mogli rekrutować się także spoza grona radnych, członków prezydium rady narodowej, czy też pracowników organów administracji państwowej. Warunkiem objęcia funkcji przewodniczącego kolegium i jego zastępcy było ukończenie studiów prawniczych, lecz wobec spodziewanych problemów z pozyskaniem prawników do pracy w kolegiach powiatowych przewidziano możliwość zwolnienia od wymogu ukończenia studiów prawniczych. Wobec przewodniczących kolegiów wojewódzkich oraz ich zastępców miał zastosowanie indywidualny tryb udzielania zwolnień przez ministra spraw wewnętrznych ${ }^{34}$.

Wydane w lutym 1959 r. rozporządzenie wykonawcze ${ }^{35}$ szeroko określało przesłanki umożliwiające osobom bez wykształcenia prawniczego obejmowanie funkcji przewodniczącego i zastępcy przewodniczącego w kolegiach szczebla powiatowego, którymi były znajomość prawa karno-administracyjnego i doświadczenie nabyte podczas pracy w aparacie obsługującym kolegia ${ }^{36}$.

31 Ustawa o orzecznictwie karno-administracyjnym. Objaśnienia i teksty, Warszawa 1959, s. 41.

32 E. Iserzon, Reforma orzecznictwa karno-administracyjnego, PiP 1959, nr 8-9, s. 260.

33 B. Bogomilski, Pozycja kolegiów karno-administracyjnych w systemie organów administracji państwowej, ZKA 1960, nr 3, s. 9.

34 H. Chmielewski, Ustawa to jeszcze nie wszystko, ZKA 1958, nr 6, s. 3.

35 Rozporządzenie Ministra Spraw Wewnętrznych z dnia 18 lutego 1959 r. w sprawie trybu i zasad zwalniania przewodniczących i zastępców przewodniczących kolegiów karno-administracyjnych przy prezydiach rad narodowych z obowiązku posiadania ukończonych studiów prawniczych (Dz. U. Nr 15, poz. 80).

36 Pierwszym kryterium uzasadniającym otrzymanie zwolnienia było ukończenie szkoły średniej 
Węższy był katalog przesłanek umożliwiających otrzymanie przez kandydatów na stanowisko przewodniczącego kolegium wojewódzkiego oraz jego zastępcy zwolnienia indywidualnego $\mathrm{z}$ rąk ministra spraw wewnętrznych, gdyż warunkiem ubiegania się o zwolnienie było posiadanie przynajmniej wykształcenia średniego oraz rocznego stażu pracy $\mathrm{w}$ aparacie karno-administracyjnym ${ }^{37}$.

Czynnik fachowy w kolegiach mieli reprezentować także przewodniczący składów orzekających, których liczbę określała w akcie wyboru członków kolegium rada narodowa. Kolejne rozporządzenie wykonawcze do znowelizowanej u.ok.a. przewidywało wybór przewodniczących składów orzekających spośród kandydatów spełniających jedną z trzech przesłanek, którymi były: wykształcenie prawnicze, znajomość zasad prawa karno-administracyjnego nabyta $\mathrm{z}$ racji pełnienia funkcji członka kolegium lub znajomość jednego z działów administracji państwowej38. Celem podniesienia poziomu pracy kolegiów odstąpiono od wymogu powoływania radnych na przewodniczących składów orzekających, znacznie rozszerzając krąg kandydatów, spośród których mógł być dokonany wybór na tę funkcję ${ }^{39}$. Jednakże licząc się z trudnościami w znalezieniu odpowiedniej liczby osób posiadających kwalifikacje fachowe, nakazano radom narodowym kierowanie się kryteriami wyboru określonymi w rozporządzeniu Ministra Spraw Wewnętrznych „w miarę możliwości”.

Wprowadzenie kryteriów, którymi powinny kierować się prezydia rad narodowych przy doborze osób przewidzianych na przewodniczących składów orzekających, stanowiło jeden z elementów procedury powoływania kolegiów. Tryb przeprowadzania wyborów członków kolegiów określało rozporządzenie Ministra Spraw Wewnętrznych, które nadało podstawy prawne dotychczasowej praktyce powoływania do kolegiów wyłącznie osób zamieszkałych lub pracujących na terenie danej rady narodowej oraz zgłaszania kandydatów przez organizacje społeczne, polityczne, związki zawodowe i załogi zakładów pracy. Jako warunek umieszczenia na liście kandydatów na członków kolegiów przewidziano pisemną zgodę kandydata wyrażoną na piśmie, co oznaczało odej-

oraz co najmniej roczny okres zatrudnienia $\mathrm{w}$ jednostce organizacyjnej prezydium rady narodowej do spraw orzecznictwa karno-administracyjnego. Z kolei osoby posiadające wykształcenie podstawowe musiały wykazać się co najmniej 3-letnim doświadczeniem w aparacie obsługującym kolegia oraz znajomością zasad prawa karno-administracyjnego. W drodze wyjątku kierownik urzędu spraw wewnętrznych prezydium wojewódzkiej rady narodowej mógł udzielić zwolnienia kandydatom z wykształceniem podstawowym, którzy pełnili obowiązki członków kolegiów w okresie dwóch poprzednich kadencji, „wykazując się aktywną pracą i znajomością zasad prawa karno-administracyjnego". O czym należy pamiętać przy wyborach do kolegiów w małych miastach, osiedlach i gromadach? "Poradnik dla Kolegiów Orzekających" (dalej: PdKO) 1959, nr 3, s. $25-26$.

$38 \S 4$ p. 3 rozporządzenia Ministra Spraw Wewnętrznych z dnia 18 lutego 1959 r. o trybie wybierania i odwoływania osób wchodzących w skład kolegiów karno-administracyjnych przy prezydiach rad narodowych oraz przewodniczących składów orzekających (Dz. U. Nr 15, poz. 81). 
ście od praktyki desygnowania do kolegiów osób tym niezainteresowanych, nawet wbrew ich woli. Oprócz określenia procedury dokonywania wyboru członków kolegium przez radę narodową w głosowaniu tajnym, nowością na tle poprzednio obowiązujących rozwiązań było wskazanie sytuacji, w których prezydium mogło wnioskować do rady narodowej o odwołanie przewodniczącego kolegium, jego zastępcy oraz poszczególnych członków kolegium. Wreszcie rozporządzenie Ministra Spraw Wewnętrznych wydłużyło kadencję kolegiów z dwóch do trzech lat, liczonych od dnia wyborów ${ }^{40}$. Ostateczne ustalenie długości kadencji kolegiów karno-administracyjnych nastąpiło w 1962 r., kiedy to rozporządzeniem Ministra Spraw Wewnętrznych ustalono zasadę wyboru kolegium na okres czteroletni ${ }^{41}$.

\section{III.}

Pod rządami znowelizowanej u.ok.a. czynniki oficjalne przykładały dużą wagę do sprawnego przeprowadzenia wyborów i zapewnienia odpowiedniej obsady personalnej kolegiów. Wychodząc ze słusznego założenia, iż „sam fakt powierzenia orzecznictwa karno-administracyjnego czynnikowi społecznemu, znającemu dane środowisko, nie stanowi odpowiedniego zabezpieczenia prawidłowego funkcjonowania tego orzecznictwa", podkreślano konieczność wprowadzenia do kolegiów czynnika fachowego ${ }^{42}$. W związku z przyznaniem kolegiom prawa orzekania aresztu zasadniczego ${ }^{43}$ dyrektor Biura Nadzoru H. Chmielewski postulował powierzenie władzy karania osobom "cechującym się nie tylko przygotowaniem zawodowym lecz także bezwzględną uczciwością, wyrobieniem społeczno-politycznym i autorytetem w swoim środowisku lokalnym". Odwołując się do doświadczeń wyniesionych z poprzednich wyborów, trafnie zauważył, iż nie można dokonać wyboru ludzi "gwarantujących prawidłowe realizowanie polityki karno-administracyjnej ustalonej przez prezydium rady narodowej [...] ustalając listy kandydatów zza biurka". Dlatego kandydatów na członków kolegiów miały wskazywać organizacje spo-

40 O czym należy pamiętać..., s. 23-27.

41 Na mocy rozporządzenia Ministra Spraw Wewnętrznych z dnia 1 marca 1962 r. (Dz. U. Nr 16, s. 71) Kadencja wybranych w 1959 r. kolegiów została przesunięta o rok na początku 1962 r. w związku ze spodziewanym wówczas wejściem w życie nowego ustawodawstwa karno-administracyjnego. Notatka w sprawie wyborów do kolegiów karno-administracyjnych działających przy prezydiach rad narodowych, IPN BU MSW II 16162, s. 39.

42 Wybory członków kolegiów karno-administracyjnych, „Sztandar Ludu” 1959, nr 44, s. 3.

43 Znowelizowana u.ok.a. przewidywała orzekanie w miejsce kary aresztu kary pracy poprawczej. Uchwalona ta 22 maja 1958 r. tzw. ustawa antychuligańska, a w ślad za nią nowelizacja u.ok.a. z 2 grudnia 1958 r. przywróciły możliwość orzekania kary aresztu w sprawach o enumeratywnie określane wykroczenia, których katalog ulegał w latach sześćdziesiątych stopniowemu rozszerzaniu. 
łeczne i związki zawodowe, które ze względu na bezpośrednią znajomość swoich ludzi były w stanie "typować kandydatów spośród swoich najlepszych członków". Celem sprawnego przeprowadzenia akcji wyborczej Chmielewski zalecał utworzenie specjalnych zespołów, które „zajęłyby się organizacją typowania kandydatów do kolegiów przez organizacje polityczne, społeczne, urzędy, instytucje państwowe i społeczne". W skład takiego zespołu mieli wchodzić „działacze społeczni województwa bądź powiatu”44, a także przedstawiciel Frontu Jedności Narodu (FJN) ${ }^{45}$.

Uwagi dyrektora Chmielewskiego posłużyły za podstawę opracowania przez MSW szczegółowych instrukcji regulujących przebieg wyborów, których termin w przypadku tworzonych z mocy ustawy kolegiów szczebla powiatowego i wojewódzkiego wyznaczono na luty-marzec 1959 r. ${ }^{46}$ Ponieważ wraz z wejściem w życie 1 marca 1959 r. nowelizacji u.ok.a. kolegia przy prezydiach rad narodowych szczebla niższego niż powiat straciły obligatoryjny charakter, stąd wybory tych kolegiów wyznaczono na okres od maja do końca listopada 1959 r. Przyjęcie takiego rozwiązania uzasadniano względami racjonalnego powoływania kolegiów szczebla niższego niż powiatowy przez rady narodowe, uważając, że powinny one starannie i bez pośpiechu rozważyć celowość podjęcia uchwały o utworzeniu kolegium. Wyznaczając półroczny okres na przeprowadzenie wyborów, kierowano się założeniem, iż „mając tak rozległy okres czasu, prezydia mogą wybrać najdogodniejszy dla nich termin oraz przygotować dobrze i na czas wybory do kolegiów"47.

Wraz z zarządzeniami określającymi termin wyborów do kolegiów minister spraw wewnętrznych wydawał skierowane do prezydiów rad narodowych instrukcje szczegółowo określające tryb przygotowywania list kandydatów oraz przebieg kampanii wyborczej. Najwięcej uwagi instrukcje poświęcały powołaniu specjalnych zespołów, w skład których mieli wchodzić działacze społeczni danego terenu, czyli „przedstawiciele partii i stronnictw politycznych, prezydium rady narodowej, komisji porządku i bezpieczeństwa publicznego rady narodowej, Komitetu Frontu Jedności Narodu”. W przypadku zespołów powołanych w związku z wyborami do kolegiów gromadzkich instrukcje MSW zalecały udział w pracach zespołu przedstawicieli kółek rolniczych, gminnych spółdzielni „Samopomoc Chłopska” oraz rolników indywidualnych. Zespoły miały zająć się ustaleniem podmiotów zgłaszających kandydatów na

44 H. Chmielewski, Ustawa to jeszcze nie wszystko, „PdKO” 1959, nr 6, s. 10.

45 Front Jedności Narodu - organizacja społeczno-polityczna utworzona w 1952 r. FJN tworzyły związki zawodowe, partie polityczne (PZPR, ZSL i SD) oraz inne organizacje społeczne i społeczno-polityczne. FJN brał aktywny udział w kampaniach wyborczych do Sejmu PRL i rad narodowych, gdyż posiadał nieoficjalny monopol na zgłaszanie kandydatów.

46 Zarządzenie Ministra Spraw Wewnętrznych z dnia 30 grudnia 1958 r. w sprawie ustalenia terminu wyborów do kolegiów przy prezydiach rad narodowych, IPN BU MSW II 6626, s. 7.

47 O czym należy pamiętać..., s. 23. 
członków kolegiów spośród organizacji politycznych i społecznych, urzędów i instytucji państwowych oraz jednostek gospodarki uspołecznionej. Na szczeblu gromadzkim kandydatów miały zgłaszać „kółka rolnicze, państwowe gospodarstwa rolne, spółdzielnie produkcyjne oraz mieszkańcy wsi na zebraniu wiejskim" ${ }^{\prime 4}$. Kolejną czynnością zespołów było zorganizowanie zebrań członków i pracowników jednostek wysuwających kandydatów celem oficjalnego zgłoszenia kandydatur. Ponadto zespoły miały dokonać analizy postawy byłych członków kolegiów celem wysunięcia kandydatur tych osób, „,które wykazały się sumienną i aktywną pracą $\mathrm{w}$ kolegium oraz znajomością zasad postępowania karno-administracyjnego". Celem umożliwienia specjalizacji składów orzekających w poszczególnych dziedzinach wykroczeń zalecano „typowanie do kolegiów fachowców - inżynierów, techników, specjalistów w dziedzinie przepisów drogowych, budowlanych, przemysłu i handlu, sanitarnych, rolnych i leśnych"49. Członkowie zespołów oraz pracownicy aparatu karno-administracyjnego mieli także czuwać nad tym, żeby przebieg zebrania nie ograniczał się jedynie do formalnego aktu wyboru kandydatów. Do ich obowiązków należało „poinformować zebranych, jaką kolegia karno-administracyjne stosują politykę represyjną, jak winny korzystać z najnowszych aktów ustawodawczych dla podniesienia skuteczności walki z wykroczeniami"50.

Równie duże znaczenie instrukcje ministra spraw wewnętrznych przykładały do wyborów członków kolegiów przez rady narodowe, zalecając przeprowadzenie wyborów na specjalnie w tym celu zwołanej sesji rady narodowej. Wyborowi odpowiednich kandydatów miało służyć udostępnienie radnym materiałów charakteryzujących sylwetki kandydatów oraz doręczenie listy kandydatów. Zalecano zaproszenie na sesję rady narodowej wszystkich kandydatów na członków kolegiów oraz przedstawicieli jednostek zgłaszających kandydatów, wybory zaś miał poprzedzić referat „wyjaśniający rolę i znaczenie kolegium karno-administracyjnego w ochronie porządku i bezpieczeństwa publicznego na terenie działania danej rady"51.

Pierwsze pod rządami znowelizowanej u.ok.a. wybory członków kolegiów były przedmiotem zainteresowania władz partyjnych, które skierowały do terenowego aparatu partyjnego specjalną instrukcję. Podpisana przez sekretarza Komitetu Centralnego Polskiej Zjednoczonej Partii Robotniczej (KC PZPR)

48 Instrukcja MSW w sprawie przeprowadzenia wyborów do kolegiów karno-administracyjnych przy prezydiach gromadzkich rad narodowych, IPN BU MSW II 6626, s. 88.

49 Instrukcja Ministra Spraw Wewnętrznych w sprawie przygotowania list kandydatów na członków kolegiów, Archiwum Akt Nowych, zespół akt Ministerstwo Sprawiedliwości, sygn. teczki 3419, s. 53.

50 Ponadto na zebraniach przedwyborczych „miały być szeroko omówione warunki, jakim powinien odpowiadać kandydat na członka kolegium”. Wybory członków..., s. 3.

51 Instrukcja MSW w sprawie przeprowadzenia wyborów do kolegiów karno-administracyjnych przy prezydiach miejskich rad narodowych miast niestanowiących powiatów miejskich i rad narodowych osiedli, IPN BU MSW II 6626, s. 93-97. 
J. Albrechta instrukcja wskazywała na potrzebę szczególnej troski terenowych instancji partyjnych o właściwy wybór członków kolegiów ze względu na znaczenie orzecznictwa karno-administracyjnego jako skutecznego „narzędzia $\mathrm{w}$ walce $\mathrm{z}$ chuligaństwem, pijaństwem i innymi zjawiskami demoralizacji społecznej". Prawidłowo przeprowadzone wybory miały zapobiec powtórzeniu się sytuacji, gdy „w kolegiach zasiadali nieraz ludzie przypadkowi, wyznaczeni w sposób biurokratyczny, bez udziału szerszego aktywu społecznego i bez rozeznania opinii środowiska, w którym żyją, pracują i działają powoływani członkowie kolegiów". Zdaniem KC PZPR do kolegiów powinni zostać wybrani „ludzie o wysokich kwalifikacjach moralno-politycznych, świadomi nałożonych na nich zadań przez władzę ludową", których terenowe organizacje partyjne powinny otoczyć "troskliwą opieką polityczną". Natomiast funkcje przewodniczącego kolegium i jego zastępcy należało powierzyć przede wszystkim kierownikom urzędów i wydziałów spraw wewnętrznych (terenowe organy administracji spraw wewnętrznych szczebla wojewódzkiego i powiatowego) jako kandydatom posiadającym $\mathrm{z}$ reguły wykształcenie prawnicze ${ }^{52}$.

Instrukcja KC PZPR przewidywała kierowanie przez członków partii „,akcją wysuwania kandydatów w zakładach pracy i wsiach" oraz aktywny udział "aktywu partyjno-społecznego" w wyborach członków kolegiów polegający m.in. na przeprowadzeniu wspólnie z radnymi analizy sylwetek kandydatów zgłoszonych przez prezydium rady narodowej. Za szczególnie istotne dla przebiegu wyborów uznano powołanie na szczeblu województw i powiatów specjalnych zespołów w celu "partyjnego kierowania akcją wyborczą", na których czele mieli stać sekretarze wojewódzcy i powiatowi PZPR ${ }^{53}$.

Wysiłek włożony ze strony aparatu spraw wewnętrznych w przygotowanie wyborów oraz aktywny udział w kampanii wyborczej terenowych instancji partyjnych miał spowodować, iż „obecna kampania wyborcza różniła się od poprzednich przede wszystkim tym, że wyszła poza mury prezydiów rad narodowych, że stała się kampanią społeczną". W odróżnieniu od poprzednich wyborów „wysuwanie kandydatów następowało bądź na zebraniach w większych zakładach pracy, bądź też na posiedzeniach zespołów wyborczych, po uprzedniej analizie moralnych, politycznych i zawodowych kwalifikacji kandydatów". Dyrektor Chmielewski podkreślał dużą aktywność terenowych instancji partyjnych „w akcji przygotowania wyborów i należytego doboru kandydatów", a zwłaszcza fakt badania przez specjalne zespoły partyjne kwalifikacji zgłoszonych kandydatów na członków kolegiów „przed ich wysunięciem na sesję rady". Upolitycznienie kampanii wyborczej skutkowało zaangażowaniem $\mathrm{w}$ jej przebieg partii sojuszniczych, zwłaszcza instancji terenowych ZSL (Zjed-

52 List KC PZPR do KW, KP (KM) PZPR w sprawie wyborów członków kolegiów karno-administracyjnych, IPN BU MSW II 6626, s. 23.

53

Ibidem, s. 24-25. 
noczonego Stronnictwa Ludowego), z kolei „nieco słabszy był udział Stronnictwa Demokratycznego (SD - przyp. Autora)". Zakrojone na szeroką skalę działania związane z przygotowaniem wyborów zyskały także odpowiednią oprawę propagandową ze stron prasy centralnej i terenowej, co pozwoliło "stworzyć w terenie odpowiedni klimat dla akcji wyborczej"54.

Wyniki wyborów do kolegiów szczebla wojewódzkiego i powiatowego oceniono pozytywnie zarówno pod kątem liczby wybranych członków kolegiów, jak też ich przygotowania fachowego. Odnotowano znaczny wzrost liczby członków kolegiów I instancji, który zdaniem dyrektora Chmielewskiego „pozwoli na zwiększenie liczby składów orzekających, a więc i szybkości orzekania, oraz umożliwi łatwiejsze opanowanie wpływu spraw". Kolejnym pozytywnym efektem wyborów był także dwukrotny wzrost liczby członków kolegiów posiadających wyższe wykształcenie, którzy stanowili 13\% stanu osobowego kolegiów. Ze względu na obowiązujący wymóg wyższego wykształcenia prawniczego przewodniczących kolegiów i ich zastępców podkreślano fakt pozyskania do pracy w kolegiach 1106 prawników, podczas gdy w poprzedniej kadencji było ich zaledwie $518^{55}$. Ponad dwukrotny wzrost liczby prawników został osiągnięty m.in. wskutek aktywnego udziału w kampanii wyborczej Zrzeszenia Prawników Polskich (ZPP), którego członkowie byli umieszczani na listach kandydatów do kolegiów przez terenowe ogniwa tej organizacji. Ponadto delegowani przez ZPP referenci „wygłaszali w zakładach pracy, organizacjach społecznych i na zebraniach wiejskich odczyty na temat znaczenia, roli i zakresu działania kolegiów karno-administracyjnych"56.

Najwięcej prawników zasiliło kolegia wojewódzkie oraz kolegia funkcjonujące $w$ dużych miastach, natomiast nie udało się pozyskać odpowiedniej liczby osób legitymujących się ukończeniem wyższych studiów prawniczych do pracy w kolegiach powiatowych. Wprawdzie liczba prawników w kolegiach powiatowych zwiększyła się o $250 \%$, lecz jak wskazywał dyrektor Chmielewski, „nadal jeszcze w poważnej ilości powiatów nie ma w kolegiach karno-administracyjnych ani jednego prawnika". Zjawisko to tłumaczono brakiem w powiatach wiejskich osób z wykształceniem prawniczym, gdyż absolwenci wydziałów prawa usiłowali "skupiać się tylko w większych ośrodkach" i ze względów prestiżowych niechętnie podejmowali pracę na prowincji ${ }^{57}$. Trudności z pozyskaniem prawników do pracy w kolegiach skutkowały koniecznością udzielenia zwolnienia z obowiązku ukończenia studiów prawniczych wobec $77 \%$ przewodniczących kolegiów powiatowych oraz ich zastępców ${ }^{58}$.

\footnotetext{
54 H. Chmielewski, Po wyborach do kolegiów karno-administracyjnych, PdKO 1959, nr 1-2, s. 1-2.

55 Ibidem, s. 3.

56 A. Maciejewski, Prawnicy do rad narodowych, PiŻ 1961, nr 7, s. 3.

57 H. Chmielewski, Po wyborach..., s. 3.

58 Wybory do kolegiów w świetle liczb, ZKA 1963, nr 3, s. 21.
} 
W wyniku przeprowadzonych w 1959 r. wyborów odnotowano poważny wzrost liczby członków kolegiów posiadających wykształcenie średnie oraz osób legitymujących się praktycznym doświadczeniem w zakresie administracji państwowej, czyli spełniających kryteria brane pod uwagę przy obsadzie funkcji przewodniczących składów orzekających. Mianem dużego osiągnięcia akcji wyborczej określono „fakt poważnego upolitycznienia składów kolegiów", gdyż połowę ich składu osobowego stanowili członkowie PZPR, licznie byli także reprezentowani członkowie ZSL ${ }^{59}$. Ponad jedna trzecia nowo wybranych członków kolegiów posiadała doświadczenie wyniesione z pracy w kolegiach poprzedniej kadencji, co miało świadczyć "o istnieniu poważnej grupy ludzi, którzy pozytywnie oceniają i poważnie traktują swą pracę w kolegiach". Jako odpowiadające przekrojowi spraw rozpatrywanych przez kolegia uznano pochodzenie społeczne ich członków, gdyż w zdecydowanej przewadze byli pracownicy umysłowi $(67 \%)$, na drugim miejscu znajdowali się robotnicy produkcyjni $(23 \%)$, chłopi zaś obsadzili 10\% miejsc w kolegiach. Skromny udział chłopów w kolegiach tłumaczono koncentracją uwagi kolegiów na rozpatrywaniu wykroczeń występujących najczęściej na terenie miasta, podczas gdy wykroczenia typowe dla stosunków wiejskich wynosiły zaledwie $15 \%$ ogółu rozpatrywanych spraw karno-administracyjnych ${ }^{60}$.

Pomimo wydania szczególnych instrukcji określających przebieg wyborów do kolegiów szczebla niższego niż powiatowy we wskazanym przez ministra spraw wewnętrznych półrocznym terminie zaledwie 3 prezydia gromadzkich rad narodowych podjęły uchwały o powołaniu kolegiów. Nieskorzystanie z możliwości tworzenia kolegiów gromadzkie rady narodowe motywowały „brakiem odpowiednio wykwalifikowanych pracowników mogących obsłużyć kolegia"61. Podobna postawa cechowała rady narodowe osiedli, wskutek czego w 1959 r. nie odbyły się wybory do kolegiów przy prezydiach osiedlowych rad narodowych. Jedynie na szczeblu miast niestanowiących powiatów rady narodowe w 76 przypadkach skorzystały z uprawnienia do powołania kolegium, co kierownictwo resortu spraw wewnętrznych określiło w 1960 r. „niedomaganiem ubiegłorocznej kampanii wyborczej"62.

Oceniając z perspektywy czasu przebieg kampanii wyborczej do kolegiów wojewódzkich i powiatowych, wskazywano na występowanie uchybień, które wpłynęły negatywnie na końcowy wynik wyborów. Przygotowując kolejne wybory do kolegiów, DSA za istotny błąd popełniony podczas kampanii wy-

$5949 \%$ członków kolegiów należało do PZPR, 8\% do ZSL, a tylko 3\% do SD. Osoby bezpartyjne stanowiły $40 \%$ składu osobowego kolegiów. Notatka w sprawie wyborów do kolegiów karno-administracyjnych działających przy prezydiach rad narodowych. IPN BU MSW II 16162, s. 41.

60 H. Chmielewski, Po wyborach..., s. 3-4.

61 Informacja o sytuacji w orzecznictwie karno-administracyjnym za I, II, III kwartał 1959 r. IPN BU MSW II 6625, s. 370.

62 Ibidem. 
borczej 1959 r. uznał niedostateczny udział w zebraniach przedwyborczych członków ustępujących kolegiów. Fakt „pominięcia w wyborach ludzi, którzy wykonując przykładnie dotychczasowe funkcje, gotowi byli je pełnić w nowej kadencji", miał zniechęcać do pracy w kolegiach aktyw społeczny. Krytykowano także lekceważące podejście niektórych rad narodowych do wyboru członków kolegiów, wskutek czego „na wielu sesjach rad narodowych kwestia wyboru członków kolegiów potraktowana była marginesowo, w porządku dziennym znajdowała się ona na przedostatnim miejscu". Formalne przeprowadzenie wyborów nie tylko utrudniało dokonanie właściwej oceny przez radę narodową pracy ustępującego kolegium ${ }^{63}$, lecz wobec braku rzetelnej analizy sylwetek kandydatów prowadziło do wyboru niewłaściwych osób. Świadczyć miał o tym fakt, iż do końca 1962 r. z funkcji członka kolegium zrezygnowało lub zostało odwołanych przez rady narodowe 1920 osób. Krytycznie oceniono także wybór zbyt małej liczby kobiet, gdyż ich kilkunastoprocentowy udział w pracy kolegiów nie odzwierciedlał struktury demograficznej społeczeństwa oraz stopnia zaangażowania kobiet w życie społeczne ${ }^{64}$.

\section{IV.}

Podsumowując na początku stycznia 1963 r. dobiegającą końca kadencję kolegiów, kierownictwo resortu spraw wewnętrznych z zadowoleniem podkreśliło, iż „w toku działalności kolegiów wyrósł aktyw, który należy utrzymać w nowo wybranych składach orzekających". Oparcie składu osobowego kolegiów na osobach posiadających doświadczenia praktyczne uznano za istotne w kontekście planowanego przekazania do orzecznictwa karno-administracyjnego „szeregu czynów, m.in. drobnych kradzieży i spekulacji” oraz postulowanego przez V Kongres Związków Zawodowych "przekazania do kolegiów naruszeń prawa pracy". Jednocześnie podkreślano potrzebę wzmocnienia obsady personalnej kolegiów, gdyż ich obecny skład osobowy „nie zupełnie odpowiada wymaganiom stawianym przed tymi organami". Cel ten zamierzano osiągnąć poprzez sprawne przeprowadzenie kampanii wyborczej do kolegiów oraz „udział w wyborach organizacji związkowych, Komitetów FJN i rad narodowych pod kierownictwem instancji partyjnych"65. Zaangażowanie komitetów partyjnych w kampanię wyborczą 1963 r. świadczy o znaczeniu, jakie władze partyjne przywiązywały do właściwej z punktu widzenia ideowo-politycznego obsady personalnej kolegiów. Oprócz utworzenia „na

63 J. Staniszewski, Przed nową kadencja, ZKA 1962, nr 1, s. 51-52.

64 Problem nr 1 - członek kolegium, ZKA 1963, numer specjalny, s. 14-15.

65 Notatka ze stycznia 1963 r. w sprawie wyborów do kolegiów karno-administracyjnych działających przy prezydiach rad narodowych, IPN BU MSW II 16162, s. 41-42. 
wszystkich szczeblach przy komitetach partyjnych roboczych zespołów, które opracują wytyczne i kalendarz wyborczy", powołano zdominowany przez przedstawicieli KC PZPR zespół centralny celem „kierowania całością kampanii wyborczej". Zespół ten miał czuwać nad sprawną realizacją poszczególnych punktów kalendarza wyborczego w skali ogólnokrajowej, począwszy od organizowania zebrań, na których „wysuwani będą kandydaci do kolegiów karno-administracyjnych", a skończywszy na "zwołaniu sesji powiatowych i wojewódzkich rad narodowych poświęconych przede wszystkim omówieniu ładu, porządku publicznego i dyscypliny społecznej oraz wyborom do kolegiów" ${ }^{\prime \prime 6}$.

Wybory 1963 r. zostały poważnie potraktowane przez kierownictwo resortu spraw wewnętrznych, o czym świadczy wydanie specjalnego numeru czasopisma „Zagadnienia Karno-Administracyjne" poświęconego w całości zbliżającej się kampanii wyborczej ${ }^{67}$. Numer specjalny otwierało przemówienie ministra spraw wewnętrznych Władysława Wichy, który w związku z planowanym przekazaniem kolegiom "szeregu czynów rozpoznawanych obecnie przez sądy" zalecał wybór obywateli „cieszących się zaufaniem społeczeństwa” i posiadających zarazem „poważny zasób wiadomości zawodowych oraz znajomość problematyki administracyjnej i stosowanego w orzecznictwie karno-administracyjnym prawa". Znaczenie udziału w kolegiach osób posiadających wiadomości fachowe w poszczególnych dziedzinach spraw o wykroczenia podkreślali przedstawiciele instytucji państwowych, organizacji związkowych i społecznych oraz dyrektorzy kilku warszawskich zakładów pracy. Zgodnie oceniając jako zbyt skromny stopień „nasycenia” fachowcami kolegiów wybranych w 1959 r., deklarowali oni chęć współpracy z zespołami terenowymi celem „przeprowadzenia prawidłowego wyboru kandydatów"68. Aktywny udział jej organizacji w procesie typowania kandydatów zapowiedziała Przewodnicząca Zarządu Głównego Ligi Kobiet, która wyraziła niezadowolenie z „dotychczasowego nasycenia kolegiów przez kobiety". Jej zdaniem orzekanie przez kolegia $\mathrm{w}$ szeregu skomplikowanych spraw wymaga nie tylko gruntownej znajomości obowiązujących w danej dziedzinie przepisów, lecz przede wszystkim cechującego kobiety w znacznie większym stopniu niż mężczyzn „społecznego wy-

66 Ibidem, s. 43-44.

67 Wybory, ZKA 1963, numer specjalny, s. 15.

68 Delegowanie swoich przedstawicieli do składów orzekających rozpatrujących sprawy z zakresu bezpieczeństwa ruchu na drogach publicznych zapowiedział wiceprzewodniczący Zarządu Głównego Związku Zawodowego Transportowców i Drogowców, natomiast do orzekania w sprawach o wykroczenia „alkoholowe” odpowiednie osoby obiecał wyznaczyć Sekretarz Generalny Głównego Komitetu Przeciwalkoholowego. Deklaracje wyznaczenia do składów orzekających osób posiadających wiadomości fachowe padły także ze strony przedstawiciela Ministerstwa Leśnictwa, Gospodarki Komunalnej oraz Ministerstwa Zdrowia i Opieki Społecznej. Mówili nam..., w: Wybory, ZKA, numer specjalny, s. 20-26. 
czucia, zrozumienia dla indywidualnych postaw i specyficznych problemów rodzinnych i sąsiedzkich". Na łamach numeru specjalnego „ZKA" swoich kandydatów w zbliżających się wyborach obiecali wystawić dyrektorzy Zakładów Radiowych im. Kasprzaka oraz Warszawskiej Fabryki Mydła i Kosmetyków, a także dyrektor handlowy "nowoczesnej placówki i dumy naszego miasta (Warszawy - przyp. Autora) "Supersamu»", który opowiadał się za udziałem pracowników handlu w rozpatrywaniu spraw o drobne kradzieże popełnione na terenie placówek handlowych ${ }^{69}$.

Numer specjalny „ZKA” zawierał też informator wyborczy, który miał „służyć pomocą zarówno komitetom, aktywowi społecznemu jak i samym urzędom i wydziałom (spraw wewnętrznych - przyp. Autora)". Zdaniem dyrektora Chmielewskiego aparat spraw wewnętrznych powinien w aktywny sposób włączyć się w prace związane z przygotowaniem wyborów, a nie tylko "ograniczać się do technicznej pomocy społecznym komitetom do spraw przygotowania wyborów". Aparat ten obarczono zadaniem sporządzenia krytycznej analizy pracy kolegiów minionej kadencji i „przedstawienia organizacjom społecznym, załogom zakładów pracy, społeczeństwu miast i wsi zarówno osiągnięć, jak i braków występujących jeszcze w pracy kolegiów"70.

Komentując na gorąco wyniki przeprowadzonych $w$ marcu i kwietniu 1963 r. wyborów, kierownictwo resortu spraw wewnętrznych stwierdziło, iż „nastąpiła dalsza jakościowa poprawa składu kolegiów”. Wzrostowi liczby członków kolegiów o ponad 3 tys. osób towarzyszyło wprowadzenie do kolegiów "dużej ilości osób, które zasiadały już w poprzedniej kadencji"71. Podczas kampanii wyborczej organizacje społeczne, polityczne oraz załogi zakładów pracy zgłosiły około 40 tys. kandydatów na członków 452 kolegiów, spośród których rady narodowe wybrały 24600 osób, w tym 9 tys. członków kolegiów poprzedniej kadencji. Pod względem pochodzenia społecznego obsadę personalną kolegiów cechowała zdecydowana przewaga inteligencji, z szeregów której rekrutowało się $64 \%$ członków kolegiów. Robotnicy obsadzili 25\% miejsc w kolegiach, natomiast $11 \%$ miejsc przypadło chłopom ${ }^{72}$.

Na tle poprzedniej kadencji wybrane w 1963 r. kolegia cechował większy stopień „upartyjnienia”, czyli udziału członków PZPR i partii sojuszniczych, w czym upatrywano gwarancję „słusznego realizowania polityki par-

69 Aktywny udział dziennikarzy w pracach nad przygotowywaniem wyborów do kolegiów poprzez ich medialne nagłośnienie i wysunięcie kandydatów do kolegiów reprezentujących środowisko dziennikarskie zapowiedział Przewodniczący Zarządu Głównego Stowarzyszenia Dziennikarzy Polskich. Podobnej treści deklarację w imieniu środowiska prawniczego złożył stojący na czele Zrzeszenia Prawników Polskich Prezes Sądu Najwyższego M. Mazur. Mówili nam..., s. 23-24.

70 Ibidem, s. 30.

71 Wybory do kolegiów w świetle liczb, ZKA 1963, nr 3, s. 20.

72 Z obrad komisji sejmowych. Orzecznictwo karno-administracyjne i realizacja k.p.a., PiŻ 1963, nr 22, s. 7. 
tii i państwa w działalności kolegiów". Pozytywnie oceniono także wzrost liczby specjalistów $\mathrm{w}$ zakresie różnych dziedzin administracji ${ }^{73}$ i życia społecznego, którym zamierzano powierzyć przewodniczenie specjalistycznym składom orzekającym. Zwiększeniu uległ też udział w kolegiach osób z wyższym wykształceniem prawniczym, ekonomicznym i technicznym z $2896 \mathrm{w}$ poprzedniej kadencji do 3898. Niespełna połowę z nich (1595 osób) stanowili absolwenci wydziałów prawa ${ }^{74}$. Zbyt mała $\mathrm{w}$ stosunku do potrzeb liczba osób legitymujących się ukończeniem wyższych studiów prawniczych powodowała trudności z obsadzeniem prawnikami wszystkich stanowisk przewodniczących kolegiów powiatowych i ich zastępców. Wskutek deficytu prawników na terenie części województw funkcjonowały kolegia powiatowe, w których składzie nie było żadnego absolwenta wydziału prawa ${ }^{75}$. Pomimo to kierownictwo Ministerstwa Spraw Wewnętrznych pozytywnie oceniło podjęte podczas kampanii wyborczej 1963 r. działania w kierunku „uzyskania na stanowiska przewodniczących kolegiów i ich zastępców osób posiadających wyższe wykształcenie". Efektem tych działań była "zmniejszona w porównaniu z poprzednią kadencją liczba zwolnień od ustawowego obowiązku posiadania ukończonych studiów prawniczych". O ile w 1959 r. udzielono takich zwolnień w stosunku do 77\% ogółu przewodniczących i ich zastępców, to po wyborach 1963 r. odsetek ten wynosił 59\%. Z wyjątkiem kilkunastu wspomnianych kolegiów szczebla powiatowego, pozostałe kolegia posiadały przewodniczącego lub zastępcę legitymujących się ukończeniem wyższych studiów prawniczych. Podkreślano zarazem ostrożne korzystanie ze zwolnień od obowiązku posiadania wyższego wykształcenia prawniczego, wskutek czego część wniosków została załatwiona odmownie z powodów formalnych ${ }^{76}$. Wobec konsekwentnej postawy prezydiów wojewódz-

73 W pierwszej połowie lat sześćdziesiątych (według danych z 1962 r.) wyższe wykształcenie posiadało 9,5\% pracowników administracji terenowej funkcjonującej $\mathrm{w}$ ramach systemu rad narodowych, spośród których prawnicy stanowili 21,2\%, ekonomiści 16,2\%, lekarze 7,5\%, pedagodzy $11 \%$, ludzie z wyższym wykształceniem rolniczym $21,2 \%$, z kolei absolwenci studiów technicznych 15,2\%. M. Osiadacz, Działacze i fachowcy, PiŻ 1965, nr 5, s. 3.

74 Jak pracuja kolegia karno-administracyjne?, „Głos Pracy” z 22 sierpnia 1963 r., s. 1.

75 Sytuacja taka miała miejsce w województwie gdańskim (w 13 kolegiach powiatowych zasiadało tylko 6 prawników), zielonogórskim (tylko połowa z 16 kolegiów posiadała w składzie prawnika) oraz koszalińskim (w 13 powiatach było jedynie 8 prawników). Znikoma liczba prawników w kolegiach szczebla powiatowego stanowiła także problem w województwie białostockim i szczecińskim, co tłumaczono „ogólnym brakiem prawników w tych rejonach kraju”. Wybory do kolegiów w świetle..., s. 20-21.

76 Przy typowaniu kandydatów na przewodniczących i zastępców niektórych kolegiów zgłaszano bowiem wnioski o zwolnienie osób nieposiadających wykształcenia średniego, przykładowo w województwie szczecińskim odrzucono 5 takich wniosków. Odmowne załatwienie wniosków pociągało za sobą konieczność ponownego wyboru przewodniczących kolegiów i ich zastępców spośród osób spełniających przewidziane przez ustawodawcę warunki uzyskania zwolnień. Ibidem, s. 22. 
kich rad narodowych wśród osób zwolnionych dominowali „absolwenci zawodowych studiów administracyjnych oraz osoby posiadające niepełne wykształcenie wyższe lub średnie i długotrwałą praktykę w orzecznictwie karno-administracyjnym" $" 77$.

W związku z upływem 4-letniej kadencji kolegium kolejne wybory członków kolegiów szczebla powiatowego i wojewódzkiego zostały wyznaczone przez ministra spraw wewnętrznych na marzec-kwiecień 1967 r. Do prawidłowego przeprowadzenia kampanii wyborczej przykładano dużą wagę ze względu na wzrost znaczenia kolegiów "w związku z przekazaniem im z dniem 1 stycznia 1967 r. z sądów niektórych drobnych przestępstw"78 i planowanym przekazaniem kolejnych występków przez komisję opracowującą projekt kodeksu karnego Polski Ludowej. Dlatego minister spraw wewnętrznych wydał zalecenie, aby „ze względu na wagę i znaczenie wyborów dla dalszej pracy kolegiów" na czele specjalnych zespołów powołanych przez prezydia rad narodowych $w$ celu przeprowadzenia wyborów stanęli przewodniczący prezydiów lub ich zastępcy. Jednocześnie minister sugerował „zaproszenie do udziału w pracach zespołów przedstawicieli stronnictw politycznych, komitetów Frontu Jedności Narodu, Związków Zawodowych, prokuratury oraz komisji ochrony porządku i bezpieczeństwa publicznego rady narodowej"79. Na łamach „Zagadnień Karno-Administracyjnych" Sekretarz Ogólnopolskiego Komitetu FJN deklarował zwrócenie przez komitety FJN szczególnej uwagi na to, "aby radom narodowym przedstawieni zostali w charakterze kandydatów na członków kolegiów aktywiści społeczni odpowiednio przygotowani do pełnienia tej funkcji". Jednocześnie zapowiedział mobilizację "całego aktywu" najniższych ogniw FJN - komitetów gromadzkich i wiejskich celem organizacji zebrań ludności wiejskiej, „na których wysunięci zostaną kandydaci na członków kolegiów"80. Z kolei sekretarz Centralnej Rady Związków Zawodowych (CRZZ) zapowiedział szerokie zaangażowanie w kampanię wyborczą "wszystkich ogniw i instancji” związków zawodowych. Wytyczne wydane przez CRZZ nakazywały terenowym instancjom związkowym delegowanie swoich przedstawicieli do wojewódzkich i powiatowych zespołów wyborczych oraz organizowania zebrań zakładowych w celu „popularyzacji dorobku kolegiów i ich roli, jak również przedstawienia swych kandydatów do kolegiów wszystkich szczebli rad narodowych" ${ }^{\prime 1}$. Aktywny udział organizacji związko-

77 Ibidem.

78 Ustawa z dnia 17 czerwca 1966 r. o przekazaniu niektórych drobnych przestępstw jako wykroczeń do orzecznictwa karno-administracyjnego (Dz. U. Nr 23, poz. 149).

79 Z pisma Ministra Spraw Wewnętrznych do przewodniczących prezydiów rad narodowych, ZKA 1963, nr 1 , s. 9.

80 Wybory, ZKA 1967, nr 1, s. 2.

81 Z pisma Ministra Spraw Wewnętrznych do przewodniczacych..., s. 9-10. 
wych w procesie typowania kandydatów przewidywały także wytyczne MSW, zgodnie z którymi „w nowo obranych kolegiach powinna się znaleźć odpowiednia reprezentacja pracowników zatrudnionych bezpośrednio w produkcji, przede wszystkim robotników i chłopów"82. Z zalecenia tego wynika, iż resort spraw wewnętrznych krytycznie ocenił fakt zdominowania składu osobowego wybranych w 1963 r. kolegiów przez pracowników umysłowych. Stanowili oni $64 \%$ ogółu członków kolegiów, podczas gdy robotników było $25 \%$, a chłopów zaledwie $11 \%$. Przedstawiciele inteligencji deklasowali pozostałe grupy społeczne stopniem pod względem zaangażowania $\mathrm{w}$ pracę składów orzekających, na co wskazywały wyniki badań aktywności członków kolegiów przeprowadzone przez Instytut Nauk Prawnych PAN w 1965 r. Udział robotników i chłopów w orzekaniu był zdecydowanie mniejszy niż pracowników umysłowych, którzy stanowili 86,6\% grupy członków kolegiów odznaczających się największą aktywnością. Wśród wyróżniających się stopniem zaangażowania członków kolegiów było tylko 11\% robotników i zaledwie 2,4\% chłopów. O braku aktywności reprezentujących środowisko wiejskie członków kolegiów świadczą dokonane podczas wspomnianych badań ustalenia, w świetle których „udział 70,5\% i tak bardzo nielicznej grupy chłopów wybranych do kolegiów można określić jako żaden lub czysto symboliczny"83.

Postulując wybór do kolegiów większej niż dotychczas liczby robotników i chłopów, resort spraw wewnętrznych zakładał jednocześnie "pozyskanie do kolegiów prawników, a także fachowców w zakresie spraw sanitarnych, rolnych, leśnych, handlowych" w związku z potrzebą specjalizacji składów orzekających. Fachowcy z zakresu administracji i poszczególnych dziedzin wykroczeń rozpatrywanych przez kolegia reprezentowali środowisko inteligenckie, podobnie jak wskazani przez ministra „dotychczasowi członkowie kolegium, którzy swą działalnością zasłużyli na ponowny wybór"84. Ze względu na potrzebę zabezpieczenia realizacji postawionych przed kolegiami zadań oraz utrzymanie ich dotychczasowego poziomu pracy zdecydowanie preferowano członków kolegiów rekrutujących się z szeregów inteligencji, stąd postulat większego udziału $\mathrm{w}$ orzecznictwie karno-administracyjnym przedstawicieli robotników i chłopów należy ocenić w kategoriach propagandy wyborczej.

Do nagłośnienia propagandowego wyborów przykładano duże znaczenie, o czym świadczy zorganizowanie w Sekretariacie Ogólnopolskiego Komitetu FJN poświęconej wyborom konferencji prasowej z „udziałem dziennikarzy reprezentujących czołowe dzienniki krajowe, radio i telewizję". Podobne konferencje zorganizowano w województwach i powiatach, czego efektem miały być liczne publikacje prasowe poświęcone orzecznictwu kolegiów i kampa-

82 Wybory..., s. 5-6.

83 J. Skupiński, Orzecznictwo kolegiów w świetle badań empirycznych, ZKA 1968, nr 4, s. 63-64.

84 Z pisma Ministra Spraw Wewnętrznych do przewodniczacych..., s. 10. 
nii wyborczej. Oceniając przebieg kampanii wyborczej, podkreślano znaczne zainteresowanie wyborami ze strony społeczeństwa, o czym świadczyć miała m.in. stosunkowo duża frekwencja na zebraniach przedwyborczych. Podczas tych zebrań „obok pozytywnej oceny dotychczasowej działalności kolegium dyskutanci wysunęli szereg wniosków pod adresem kolegiów”, w tym żądania „zaostrzenia represji w stosunku do sprawców wykroczeń o charakterze chuligańskim i wykroczeń drogowych, a także w stosunku do sprawców nigdzie nie pracujących i recydywistów" ${ }^{\prime 2}$. Wybory członków kolegiów przez rady narodowe odbyły się w sposób uwzględniający zalecenia ministra spraw wewnętrznych i KC PZPR, gdyż „niektóre sesje rad narodowych na szczeblu powiatowym poświęcone były wyłącznie sprawom dotyczącym porządku i bezpieczeństwa publicznego oraz wyborom do kolegiów". W przypadku wojewódzkich rad narodowych „,wybory stanowiły z reguły jeden z punktów porządku obrad, obok takich spraw jak wykonawstwo planu gospodarczego i budżetu". W niektórych sesjach rad narodowych szczebla wojewódzkiego wzięli udział przedstawiciele utworzonego z inicjatywy KC PZPR Centralnego Zespołu Wyborczego, natomiast członkowie wojewódzkich zespołów wyborczych uczestniczyli w sesjach rad szczebla powiatowego. Podkreślano przy tym fakt przeprowadzania podczas sesji dyskusji dotyczących aktualnych problemów orzecznictwa karno-administracyjnego na danym terenie. Tytułem przykładu wskazano sesję Wojewódzkiej Rady Narodowej w Bydgoszczy, podczas której „zwrócono uwagę na potrzebę zapewnienia lepszych warunków lokalowych dla pracy kolegiów oraz otoczenia większą opieką członków kolegiów jako działaczy społecznych" 86 .

W wyniku przeprowadzonych w marcu i kwietniu 1967 r. wyborów obsada personalna kolegiów szczebla powiatowego i wojewódzkiego uległa zwiększeniu o około 8\%, co uzasadniano „zwiększeniem zadań kolegiów w związku z przekazaniem im niektórych spraw rozpatrywanych dotychczas przez sądy". Prawie połowa nowo wybranych członków posiadała praktyczne doświadczenie nabyte podczas pracy w kolegiach minionych kadencji, wskutek czego skład polityczny i socjalny kolegiów nie uległ istotnym zmianom. Kierujący DSA Zygmunt Orłowski (w 1964 r. zastąpił Henryka Chmielewskiego) pozytywnie ocenił wybór do kolegiów większej niż poprzednio liczby kobiet (19,2\% ogółu wybranych na tle 17,1\% w poprzedniej kadencji) oraz fakt, iż „pozyskano więcej prawników i fachowców”. Pomimo nieznacznego (o 0,7\%) wzrostu liczby prawników w kolegiach, ich udział procentowy w obsadzie orzeczeń do wiadomości w miejscach pracy, składanie przez członków kolegium przed załogą macierzystego zakładu pracy informacji o swojej działalności". Ibidem. 
personalnej kolegiów szczebla powiatowego uważano za zbyt niski w stosunku do potrzeb. W niektórych powiatach kolegia nie posiadały w swoim składzie ani jednego prawnika, lecz $\mathrm{w}$ przeciwieństwie do poprzedniej kadencji po wyborach 1967 r. sytuacje takie należały do rzadkości. Odnotowano natomiast poprawę poziomu wykształcenia i przygotowania fachowego nowo wybranych przewodniczących składów orzekających, gdyż $23 \%$ spośród nich legitymowało się ukończeniem wyższych studiów prawniczych, $18 \%$ posiadało wykształcenie wyższe nieprawnicze, prawie $50 \%$ wykształcenie średnie, a tylko $9 \%$ zakończyło edukację na poziomie szkoły podstawowej. Podsumowując wyniki wyborów przeprowadzonych w 1967 r., dyrektor Orłowski pozytywnie ocenił fakt „pozyskania dla kolegiów najbardziej wartościowych, cieszących się autorytetem przedstawicieli społeczeństwa, osób na ogół dobrze przygotowanych do wykonywania trudnych zadań stojących przed orzecznictwem" ${ }^{\prime \prime 7}$.

\section{V.}

Wprawdzie kadencja wybranych w 1967 r. kolegiów upływała w kwietniu 1971 r., lecz w oczekiwaniu na wejście w życie ustaw składających się na całościową kodyfikację prawa wykroczeń minister spraw wewnętrznych zdecydował o przedłużeniu kadencji kolegiów do końca roku. Termin wyborów wyznaczono na wrzesień i październik 1971 r., wskutek czego nowo wybrani członkowie kolegiów rozpoczęli swoją pracę 1 stycznia 1972 r., czyli w dniu wejścia $w$ życie nowego prawa o wykroczeniach ${ }^{88}$. Odpadła zatem konieczność zapoznawania członków kolegiów z przepisami dotychczas obowiązującymi, co umożliwiło skupienie uwagi kadry szkoleniowej „na zapoznaniu z nowymi przepisami prawa o wykroczeniach i procedury" 89 . Oceniając pozytywnie decyzję o wydłużeniu kadencji kolegiów, za którą miały przemawiać „słuszne względy praktyczne i ekonomiczne” wskazywano także na fakt, iż „wybory odbywały się w nowym, korzystnym klimacie politycznym stworzonym uchwałami VII i VIII Plenum KC PZPR"90.

Przeprowadzone w październiku i listopadzie 1971 r. wybory odbyły się „W oparciu o nowe przepisy określające, kto może kandydować do kolegium"91. Przepisy te zostały zamieszczone w uchwalonej 20 maja $1971 \mathrm{r}$. usta-

\footnotetext{
87 Ibidem, s. 4-5.

88 J. Smereczański, W obliczu nowych zadań, ZW 1972, nr 1, s. 3.

89 Motywy decyzji, ZKA 1971, nr 1, s. 17-18.

90 M. Rybicki, Jubileusz i refleksje, ZKA 1971, nr 6, s. 7.

91 Motywy decyzji..., s. 17-18.
} 
wie o ustroju kolegiów do spraw wykroczeń ${ }^{92}$ (u.k.s.w.), która nie zmieniała w sposób istotny procedury wyboru członków kolegiów ukształtowanej pod rządami u.ok.a. Kodyfikacji prawa wykroczeń Polski Ludowej, pozostała przy dotychczasowej koncepcji kolegium jako organu o składzie społecznym wybieranym przez radę narodową ${ }^{93}$. W związku z tym uważam, iż analiza poszczególnych rozwiązań obowiązującej od 1 stycznia 1972 r. u.k.s.w. powinna zostać przeprowadzona $\mathrm{w}$ ramach rozważań poświęconych kodyfikacji prawa wykroczeń Polski Ludowej. Na łamach niniejszego artykułu zostanie natomiast przedstawiony przebieg wyborów do kolegiów przeprowadzonych w 1971 r., gdyż wybory te odbyły się jeszcze pod rządami u.ok.a. według schematu wypracowanego $\mathrm{w}$ okresie gomułkowskim.

Zgodnie z dotychczasową praktyką "w przygotowywaniu wyborów brały udział komitety FJN, a kandydatury członków kolegiów zostały wysunięte w czasie zebrań przedwyborczych przez załogi zakładu i zebrania mieszkańców"94. Oprócz spotkań w zakładach pracy i na zebraniach wiejskich szeroko wykorzystano środki masowego przekazu "celem popularyzacji nowych ustaw i orzecznictwa kolegiów"95. Podkreślano także duże zainteresowanie osób biorących udział $\mathrm{w}$ zebraniach przedwyborczych bieżącymi problemami występującymi w pracy kolegiów, co miało miejsce m.in. na terenie miasta Rzeszowa. Większość zebranych domagała się zaostrzenia represji w stosunku do „chuliganów i osób, które pod wpływem alkoholu zakłócają spokój na ulicach miasta" oraz sprawców wykroczeń drogowych, lecz pojawiły się także postulaty odejścia od zbyt surowej represji w sprawach o wykroczenia nieposiadające dużego ładunku szkodliwości społecznej. Na potrzebę złagodzenia wymierzanych przez kolegia kar wskazywali zwłaszcza pracownicy placówek handlowych pociągani do odpowiedzialności „zarówno za wykroczenia związane z działaniem na szkodę konsumentów, jak i na nieoznaczenie cen na towarach oraz naruszanie przepisów sanitarnych" ${ }^{\prime \prime}$.

Wyłoniona w wyniku przeprowadzonych $\mathrm{w}$ drugiej połowie $1971 \mathrm{r}$. wyborów obsada personalna kolegiów była liczniejsza niż w poprzedniej kadencji, co było zgodne z utrzymującą się od wyborów $1957 \mathrm{r}$. tendencją systematycznego wzrostu liczby członków kolegiów. Podobnie jak dotychczas decyzję prezydiów rad narodowych o zwiększeniu liczby członków kolegiów uzasadniano „nowymi zadaniami i przewidywanym wzrostem liczby spraw, które będą kiero-

92 Dz. U. Nr 12, poz. 117.

93 Studium $w$ zakresie organizacji i funkcjonowania kolegiów do spraw wykroczeń I-szej instancji w województwie stołecznym warszawskim, [w:] Prace i materiały techniczno-ekonomicznej rady naukowej przy prezydencie miasta stołecznego Warszawy, 1980, nr 86, s. 8.

94 M. Rybicki, Jubileusz..., s. 7.

95 E. Pacholarz, Nowo wybrane kolegia - w liczbach, ZKA 1972, nr 1, s. 22-23.

96 E. Lentyński, Udana kampania, ZW 1972, nr 1, s. 28-29. 
wane do kolegiów". Prawie 42\% osób wybranych do kolegiów szczebla powiatowego i 47,6\% zasiadających w kolegiach II instancji posiadało doświadczenie praktyczne związane $\mathrm{z}$ pełnieniem funkcji członka kolegium $\mathrm{w}$ poprzednich kadencjach $^{97}$.

W porównaniu do poprzednich dwóch kadencji nie uległ większym zmianom „skład kolegiów pod względem socjalnym, wykształcenia i przynależności partyjnej", chociaż podkreślano fakt większego niż poprzednio udziału kobiet. Największy odsetek kobiet (37\% przy średniej krajowej 23\%) zasiadał w kolegiach dzielnicowych miasta Łodzi ze względu na wysoki wskaźnik ich zatrudnienia $w$ przemyśle włókienniczym ${ }^{98}$. Przeprowadzona przez kierownictwo DSA analiza składu socjalnego kolegiów miała wykazać, iż „zapewniona została $\mathrm{w}$ zasadzie prawidłowa reprezentacja różnych grup zawodowych i środowiskowych". Podobnie jak dotychczas w kolegiach przeważali pracownicy umysłowi, spośród których tzw. inteligencja techniczna (technicy i inżynierowie zatrudnieni w przemyśle) stanowiła w skali krajowej 12\% ogółu członków kolegiów, pozostali zaś pracownicy umysłowi 32,9\% ${ }^{99}$.

W zakresie wykształcenia członków kolegiów za pozywane zjawisko uznano „pozyskanie większej liczby prawników, zwłaszcza w kolegiach powiatowych", wobec czego w skali ogólnokrajowej prawnicy stanowili 6,8\% członków kolegiów I instancji. Najmniej prawników obsadziło kolegia powiatowe w województwach gdańskim (3,9\%), warszawskim $(4 \%)$ i bydgoskim $(4,4 \%)$, stąd na terenie tych województw występowała „stosunkowo duża liczba przewodniczących lub zastępców przewodniczących kolegiów, którzy nie posiadają wykształcenia prawniczego". Pociągało to za sobą konieczność udzielania zwolnień z obowiązku ukończenia wyższych studiów prawniczych, których w skali całego kraju udzielono 305 przewodniczącym kolegiów I instancji oraz ich zastępcom. Zdecydowanie wyższy był wskaźnik udziału prawników w kolegiach odwoławczych, gdyż wynosił on 19,4\% ogółu członków. Również ogólny poziom wykształcenia członków kolegiów wojewódzkich prezentował się lepiej niż osób wybranych do kolegiów powiatowych. Na obydwu szczeblach kolejny raz odnotowano wzrost liczby absolwentów studiów wyż-

97 Jako przykład podawano Katowice i Poznań, gdzie ponad połowa członków kolegiów dzielnicowych orzekała już w poprzedniej kadencji. E. Pacholarz, op. cit., s. 25.

98 Ibidem, s. 23.

99 Nieznacznemu zwiększeniu na tle poprzedniej kadencji uległ udział robotników w kolegiach, których najwięcej wybrano w Łodzi $(36,8 \%)$ i woj. poznańskim $(33,1 \%)$, najmniej zaś w województwach o przeważającej strukturze rolniczej. Najliczniejsza reprezentacja rolników zasiadała w kolegiach woj. lubelskiego (19\% ogółu członków), lecz w skali całego kraju odnotowano mniejszy niż poprzednio udział chłopów, który był symboliczny w województwach typowo przemysłowych ( $2 \%$ w woj. katowickim). W kolegiach zasiadła także niezbyt liczna $(7,4 \%)$ grupa osób niepracujących zawodowo, w skład której wchodzili emeryci, renciści, gospodynie domowe i studenci. E. Pacholarz, op. cit., s. 24. 
szych niebędących prawnikami ${ }^{100}$, co miało znaczenie $\mathrm{w}$ kontekście zapewnienia odpowiedniego kierownictwa składów orzekających kolegiów. W przeciwieństwie do rozwiązań dotychczasowych u.k.s.w. nie przewidywała funkcji przewodniczących składów orzekających, wskutek czego rozprawie mógł przewodniczyć każdy z członków kolegiów wyznaczony przez przewodniczącego kolegium ${ }^{101}$. Wprawdzie u.k.s.w. nie wspominała o kwalifikacjach członków kolegium wyznaczanych celem przewodniczenia na rozprawie, lecz nawiązując do praktyki okresu gomułkowskiego, funkcję tę z reguły powierzano „osobom z wyższym wykształceniem, specjalistom $\mathrm{w}$ różnych działach administracji oraz długoletnim, doświadczonym członkom kolegiów"102. Podczas wyborów $1971 \mathrm{r}$. brano także pod uwagę przewidziane $\mathrm{w}$ kodyfikacji procesowego prawa wykroczeń ograniczenie udziału pracowników prezydium rady narodowej w pracach składów orzekających kolegiów ${ }^{103}$. W związku z tym ograniczeniem za prawidłowy uznano przeciętny wskaźnik udziału pracowników prezydiów rad narodowych w ogólnej liczbie członków kolegiów na poziomie 13,6\%.

Pierwszy raz w dziejach kolegiów przeprowadzono także analizę składu kolegiów pod względem wieku ich członków, która wykazała zdecydowaną przewagę osób w średnim wieku. Tylko 13\% członków kolegiów nie ukończyło 30 lat, a 9,4\% było $\mathrm{w}$ wieku powyżej 60 lat. W zakresie przynależności partyjnej członków kolegiów wybranych w 1971 r. odnotowano 3-procentowy spadek liczby członków PZPR i partii sojuszniczych, co posłużyło za podstawę do sformułowania tezy o potrzebie "szerszego włączania bezpartyjnych do działalności społecznej w kolegiach". W rzeczywistości wzrost liczby osób bezpartyjnych do 35,8\% ogólnej liczby członków kolegiów nie zmienił w sposób istotny stopnia "upartyjnienia” kolegiów, gdyż połowa obsady kadrowej kolegiów należała do PZPR (51,9\%), około 9\% do ZSL, członkowie SD stanowili zaś $3,5 \%{ }^{104}$.

\section{Wnioski}

Leżąca u podstaw przeprowadzonej $\mathrm{w}$ grudniu $1951 \mathrm{r}$. socjalistycznej reformy modelu orzecznictwa $\mathrm{w}$ sprawach o wykroczenia idea zastąpienia elementów biurokratycznych czynnikiem społecznym stanowiła podstawową

100 W kolegiach wojewódzkich zasiadało $15,1 \%$ osób posiadających wyższe wykształcenie nieprawnicze, podczas gdy w powiatach odpowiednio 7,7\%. Tylko 28,9\% członków kolegiów wojewódzkich legitymowało się wykształceniem podstawowym, podczas gdy w kolegiach I instancji aż 40,2\%. Ibidem, s. 25-26.

101 J. Lewiński, Ustrój kolegiów do spraw wykroczeń, „Służba MO” 1971, nr 2, s. 207.

102 E. Pacholarz, op. cit., s. 25.

103 Art. $17 \S 3$ u.k.s.w.

104 E. Pacholarz, op. cit., s. 25. 
przyczynę niskiego poziomu funkcjonowania kolegiów orzekających w okresie stalinowskim. Wprawdzie personalno-organizacyjna struktura kolegiów została ukształtowana na podobieństwo sądu orzekającego z udziałem ławników ${ }^{105}$, lecz brak wymogu wykształcenia prawniczego względem przewodniczących kolegiów i ich zastępców skutkował brakiem w składach kolegiów osób posiadających znajomość skomplikowanej materii prawa karno-administracyjnego. Oprócz braku fachowego kierownictwa przyczyną szeregu uchybień w pracy kolegiów było szeroko stosowane w praktyce rozwiązanie u.ok.a. przewidujące pełnienie funkcji przewodniczącego składu orzekającego przez członka kolegium piastującego jednocześnie mandat radnego.

Wraz z objęciem steru rządów w Polsce przez Władysława Gomułkę zarówno doktryna, jak też czynniki oficjalne dostrzegły potrzebę wprowadzenia do kolegiów czynnika fachowego jako niezbędnego warunku dalszego funkcjonowania socjalistycznego modelu orzecznictwa karno-administracyjnego. Uchwalona 2 grudnia 1958 r. nowelizacja u.ok.a. ograniczała rolę aktywu społecznego, gdyż na kluczowych dla praktycznego funkcjonowania kolegiów stanowiskach preferowała osoby posiadające wykształcenie prawnicze. Stawiany przewodniczącym kolegiów wojewódzkich i powiatowych wymóg ukończenia studiów prawniczych niewątpliwie wzmacniał kolegia pod względem fachowym, lecz praktyczne znaczenie tego rozwiązania osłabiały występujące $\mathrm{w}$ okresie gomułkowskim problemy z pozyskaniem absolwentów studiów prawniczych do pracy w kolegiach. Wobec nierównomiernego nasycenia kolegiów prawnikami, którzy szczególną niechęcią darzyli kolegia powiatowe położone $\mathrm{z}$ dala od ośrodków miejskich, wprowadzona jako wyjątek od reguły możliwość zwolnienia przewodniczących kolegiów i ich zastępców od obowiązku ukończenia studiów prawniczych była powszechnie stosowanym rozwiązaniem. Wprawdzie kolejne wybory do kolegiów przynosiły systematyczny wzrost liczby osób z wykształceniem prawniczym, lecz jeszcze w 1971 r. „na 455 istniejących kolegiów aż w 305 przypadkach udzielono przewodniczącym tych kolegiów i ich zastępcom zwolnień od obowiązku posiadania ukończonych studiów prawniczych"106. Problemy z pozyskaniem prawników do pracy $w$ kolegiach były przyczyną powierzania funkcji przewodniczących składów orzekających osobom legitymującym się wyższym wykształceniem nieprawniczym lub posiadającym doświadczenie $\mathrm{w}$ pracy administracyjnej, chociaż u.ok.a. zalecała obsadzanie tych stanowisk prawnikami. Wobec trudności natury obiektywnej pozytywnie należy ocenić powszechną w okresie gomułkowskim praktykę wyznaczania na przewodniczących składów orzekających członków kolegiów, którzy posiadali wiedzę fachową w określonych dziedzinach spraw karno-administracyjnych.

105 J. Skupiński, Model polskiego..., s. 116.

106 J. Pacholarz, op. cit., s. 25. 
Pod rządami znowelizowanej u.ok.a. zdecydowanej poprawie uległa organizacja wyborów członków kolegiów, gdyż oparty dotychczas na pozaprawnej praktyce przebieg wyborów został dosyć szczegółowo uregulowany $\mathrm{w}$ rozporządzeniu wykonawczym do u.ok.a. Kluczową rolę w podniesieniu rangi społecznej wyborów należy przypisać ich upolitycznieniu, gdyż dominująca rola partii komunistycznej w życiu społeczno-politycznym gwarantowała udział $\mathrm{w}$ wyborach szeregu podmiotów oraz odpowiednie nagłośnienie propagandowe wyborów. Zanim partia komunistyczna aktywnie włączyła się do kampanii wyborczej, ciężar jej przeprowadzenia spoczywał wyłącznie na barkach aparatu Ministerstwa Spraw Wewnętrznych, które wobec braku odpowiedniej siły przebicia nie było $\mathrm{w}$ stanie zapobiec formalnemu traktowaniu wyborów przez podmioty typujące kandydatów, jak też dokonujące wyboru członków kolegiów rady narodowe. Począwszy od wyborów 1959 r., notowano stały wzrost liczby członków kolegiów ${ }^{107}$, co miało istotne znaczenie dla zapewnienia sprawnego funkcjonowania orzecznictwa karno-administracyjnego $\mathrm{w}$ obliczu stałego rozszerzenia zakresu spraw o wykroczenia podlegających jurysdykcji kolegiów. Mająca miejsce w latach sześćdziesiątych stopniowa poprawa poziomu pracy kolegiów została osiągnięta kosztem odejścia od „zasady udziału szerokich kręgów społeczeństwa” w wykonywaniu orzecznictwa w sprawach o wykroczenia. Wprawdzie dla potrzeb propagandowych podkreślano fakt, iż w ciągu 20 lat obowiązywania u.ok.a. „w kolegiach karno-administracyjnych zasiadało ponad 200000 osób, w tym, ponad $54 \%$ robotników i chłopów" ${ }^{\prime 108}$, lecz w praktyce obsada personalna kolegiów była zdominowana przez pracowników umysłowych. Przedstawiciele inteligencji najczęściej zasiadali w składach orzekających kolegiów, którym przewodniczyli $\mathrm{z}$ reguły posiadający $\mathrm{ku}$ temu odpowiednie kwalifikacje pracownicy prezydiów rad narodowych ${ }^{109}$. Powierzanie funkcji przewodniczenia na rozprawie pracowników prezydiów rad narodowych uzasadniano względami techniczno-organizacyjnymi, gdyż dostępność tych pracowników umożliwiała zapewnienie pełnej obsady na posiedzeniach składów orzekających. Wśród przewodniczących kolegiów panował pogląd, iż "tylko dzięki udziałowi pracowników prezydiów (którzy są łatwo osiągalni, znajdują się na miejscu) udaje się zapewnić prawidłowe funkcjonowanie kolegiów ${ }^{110}$. Ponieważ funkcje przewodniczących kolegiów i ich zastępców pełnili przeważnie członkowie prezydiów rad narodowych, stąd faktyczne kierowanie zarówno pracami kole-

107 W 1959 r. do kolegiów wybrano 21201 osób, 1963 r. - 24 608, 1967 r. - 26860 i w 1971 r. - 30725. Ibidem, s. 23.

108 J. Jendrośka, Przebyta droga, ZKA 1971, nr 6, s. 14.

109 M. Olszewski, Kontrola sądowa nad orzecznictwem w sprawach o wykroczenia - de lege ferenda, PiP 1976, nr 1-2, s. 191.

110 J. Skupiński, Orzecznictwo kolegiów w świetle..., s. 65. 
giów, jak i poszczególnych składów orzekających spoczywało w rękach czynnika biurokratycznego ${ }^{111}$. Dominująca rola pracowników prezydiów rad narodowych w wykonaniu orzecznictwa karno-administracyjnego pomniejszała znaczenie leżącej u podstaw uchwalenia u.ok.a. zasady szerokiego udziału aktywu społecznego $\mathrm{w}$ rozstrzyganiu spraw o wykroczenia ${ }^{112}$, która $\mathrm{w}$ realiach Polski gomułkowskiej miała wydźwięk głównie propagandowy. Obsadzanie kluczowych dla funkcjonowania orzecznictwa karno-administracyjnego stanowisk pracownikami prezydiów rad narodowych prowadziło także do faktycznego podporządkowania kolegiów terenowym organom administracji państwowej, wbrew oficjalnie lansowanej przez doktrynę tezie o niezawisłości kolegiów sprawujących tzw. mały wymiar sprawiedliwości w sprawach o wykroczenia ${ }^{113}$.

\section{Bibliografia}

\section{Akty prawne}

Ustawa z dnia 15 grudnia 1951 r. o orzecznictwie karno-administracyjnym (Dz. U. $\mathrm{Nr} 66$, poz. 454).

Rozporządzenie Rady Ministrów z dnia 15 grudnia 1951 r. w sprawie trybu wybierania i odwoływania członków kolegiów przy prezydiach rad narodowych (Dz. U. Nr 66, poz. 455).

Ustawa z dnia 2 grudnia 1958 r. o zmianie ustawy z dnia 15 grudnia 1951 r. o orzecznictwie karno-administracyjnym (Dz. U. Nr 77, poz. 396).

Rozporządzenie Ministra Spraw Wewnętrznych z dnia 18 lutego 1959 r. w sprawie trybu i zasad zwalniania przewodniczących i zastępców przewodniczących kolegiów karno-administracyjnych przy prezydiach rad narodowych z obowiązku posiadania ukończonych studiów prawniczych (Dz. U. Nr 15, poz. 80).

\section{Archiwalia}

Instytut Pamięci Narodowej w Warszawie, Biuro Udostępniania i Archiwizacji Dokumentów, Zespół akt Ministerstwo Spraw Wewnętrznych II, sygn. teczek: 3419, 6439, 6443, 6625, 6626, 16155, 16162.

111 Idem, Skład społeczny kolegiów..., s. 112-113.

112 Już w 1962 r. zwrócił na to uwagę M. Broniatowski, op. cit., s. 73.

113 Twierdził tak m.in. M. Siewierski, Założenia ogólne orzecznictwa k-a, ZKA 1964, nr 5, s. 55-56. 


\section{Monografie}

Jaroszyński M., Zagadnienia rad narodowych, Warszawa 1961.

Leoński Z., Rady narodowe. Zasady funkcjonowania i organizacja, Warszawa 1969.

Skupiński J., Model polskiego prawa o wykroczeniach, Warszawa 1974.

Ustawa o orzecznictwie karno-administracyjnym. Objaśnienia i teksty, Warszawa 1959.

Wendel A., Zell Z., Rady narodowe w PRL, Warszawa 1968.

\section{Artykuły}

Bogomilski B., Pozycja kolegiów karno-administracyjnych w systemie organów administracji państwowej, ZKA 1960, nr 3.

Broniatowski M., Perspektywy uspołecznienia orzecznictwa karno-administracyjnego, PiP 1962, nr 7.

Chmielewski H., Po wyborach do kolegiów karno-administracyjnych, PdKO 1959, nr 1-2.

Chmielewski H., Ustawa to jeszcze nie wszystko, PdKO 1959, nr 6.

Głos maja przedstawiciele nauki, ZKA 1961, nr 6.

Hibner J., Ludzie władzy terenowej, PiŻ 1961, nr 8.

Iserzon E., Reforma orzecznictwa karno-administracyjnego, PiP 1959, nr 8-9.

Jak pracuja kolegia karno-administracyjne?, „Głos Pracy” z 22 sierpnia 1963 r.

Jendrośka J., Przebyta droga, ZKA 1971, nr 6.

Lentyński E., Udana kampania, ZW 1972, nr 1.

Lewiński J., Ustrój kolegiów do spraw wykroczeń, „Służba MO” 1971, nr 2.

Maciejewski A., Prawnicy do rad narodowych, PiŻ 1961, nr 7.

Motywy decyzji, ZKA 1971, nr 1.

O czym należy pamiętać przy wyborach do kolegiów w małych miastach, osiedlach i gromadach?, PdKO 1959, nr 3, s. 25-26.

Olszewski M., Kontrola sądowa nad orzecznictwem w sprawach o wykroczenia - de lege ferenda, PiP 1976, nr 1-2.

Osiadacz M., Działacze i fachowcy, PiŻ 1965, nr 5.

O ustroju kolegiów do spraw wykroczeń, ZKA 1971, nr 3, s. 19.

Pacholarz E., Nowo wybrane kolegia - w liczbach, ZKA 1972, nr 1.

Problem nr 1 - członek kolegium, ZKA 1963, nr specjalny.

Przybysiak I., Od „Biuletynu” do "Zagadnień Wykroczeñ", ZW 1976, nr 2.

Rybicki M., Jubileusz i refleksje, ZKA 1971, nr 6.

Rybicki Z., Gospodarcze aspekty orzecznictwa karno-administracyjnego, „Przegląd Ustawodawstwa Gospodarczego" 1952, nr 9.

Rybicki Z., Sobczak K., O niektórych zagadnieniach udziału obywateli w orzecznictwie karno-administracyjnym, „Nowe Prawo” 1957, nr 4.

Siewierski M., Założenia ogólne orzecznictwa k-a, ZKA 1964, nr 5. 
Skupiński J., Skład społeczny kolegiów karno-administracyjnych, „Problemy Rad Narodowych" 1969, nr 14.

Smereczański J., W obliczu nowych zadań, ZW 1972, nr 1.

Staniszewski J., Przed nowa kadencja, ZKA 1962, nr 1.

Studium w zakresie organizacji i funkcjonowania kolegiów do spraw wykroczeń I-szej instancji w województwie stołecznym warszawskim, [w:] Prace i materiały techniczno-ekonomicznej rady naukowej przy prezydencie miasta stołecznego Warszawy, 1980, nr 86.

Wybory, ZKA 1967, nr 1.

Wybory członków kolegiów karno-administracyjnych, „Sztandar Ludu” 1959, nr 44.

Wybory do kolegiów w świetle liczb, ZKA 1963, nr 3.

"Zadaniem MSW jest walka ze wszelkimi jawnymi lub ukrytymi formami dyskryminacji narodowej..." - wywiad z Ministrem Spraw Wewnętrznych Władysławem Wicha, PiŻ 1956, nr 5.

Ziarkiewicz K., Kształtowanie się ustroju kolegiów, ZW 1977, nr 4-5.

Zimmermann M., Orzecznictwo karno-administracyjne, ZKA 1965, nr 4.

$Z$ obrad komisji sejmowych. Orzecznictwo karno-administracyjne i realizacja k.p.a., PiŻ 1963, nr 22.

Z pisma Ministra Spraw Wewnętrznych do przewodniczacych prezydiów rad narodowych, ZKA 1963, nr 1. 